University of Nebraska - Lincoln

DigitalCommons@University of Nebraska - Lincoln

2009

\title{
Heterogeneous reduction of $\mathrm{Tc}(\mathrm{VII})$ by $\mathrm{Fe}(\mathrm{II})$ at the solid-water interface
}

\author{
T. Peretyazhko \\ Pacific Northwest National Laboratory, tetyana.peretyazhko@pnl.gov
}

John M. Zachara

Pacific Northwest National Laboratory, john.zachara@pnl.gov

S.M. Heald

Argonne National Laboratory

B.-H. Jeon

Yonsei University

Ravi K. Kukkadapu

Pacific Northwest National Laboratory, ravi.kukkadapu@pnl.gov

See next page for additional authors

Follow this and additional works at: https://digitalcommons.unl.edu/usdoepub

Part of the Bioresource and Agricultural Engineering Commons

Peretyazhko, T.; Zachara, John M.; Heald, S.M.; Jeon, B.-H.; Kukkadapu, Ravi K.; Liu, C.; Moore, D.; and Resch, C.T., "Heterogeneous reduction of Tc(VII) by Fe(II) at the solid-water interface" (2009). US Department of Energy Publications. 163.

https://digitalcommons.unl.edu/usdoepub/163

This Article is brought to you for free and open access by the U.S. Department of Energy at DigitalCommons@University of Nebraska - Lincoln. It has been accepted for inclusion in US Department of Energy Publications by an authorized administrator of DigitalCommons@University of Nebraska - Lincoln. 


\section{Authors}

T. Peretyazhko, John M. Zachara, S.M. Heald, B.-H. Jeon, Ravi K. Kukkadapu, C. Liu, D. Moore, and C.T. Resch 


\title{
Heterogeneous reduction of $\mathrm{Tc}(\mathrm{VII})$ by $\mathrm{Fe}(\mathrm{II})$ at the solid-water interface
}

\author{
T. Peretyazhko ${ }^{\text {a,* }}$, J.M. Zachara ${ }^{\text {a }}$, S.M. Heald ${ }^{\text {c }}$, B.-H. Jeon ${ }^{\text {b }}$, R.K. Kukkadapu ${ }^{\text {a }}$, \\ C. Liu ${ }^{a}$, D. Moore ${ }^{a}$, C.T. Resch ${ }^{a}$ \\ a Pacific Northwest National Laboratory, P.O. Box 999, MS K8-96, Richland, WA 99354, USA \\ ${ }^{\mathrm{b}}$ Yonsei University, Kangwon-Do 220-710, Republic of Korea \\ ${ }^{\mathrm{c}}$ Argonne National Laboratory, Argonne, IL 60439, USA
}

Received 7 September 2007; accepted in revised form 11 January 2008; available online 26 January 2008

\begin{abstract}
Experiments were performed herein to investigate the rates and products of heterogeneous reduction of $\mathrm{Tc}(\mathrm{VII}) \mathrm{by} \mathrm{Fe}(\mathrm{II})$ adsorbed to hematite and goethite, and by $\mathrm{Fe}(\mathrm{II})$ associated with a dithionite-citrate-bicarbonate (DCB) reduced natural phyllosilicate mixture [structural, ion-exchangeable, and edge-complexed $\mathrm{Fe}(\mathrm{II})$ ] containing vermiculite, illite, and muscovite. The heterogeneous reduction of $\mathrm{Tc}(\mathrm{VII})$ by $\mathrm{Fe}(\mathrm{II})$ adsorbed to the $\mathrm{Fe}(\mathrm{III})$ oxides increased with increasing $\mathrm{pH}$ and was coincident with a second event of $\mathrm{Fe}^{2+}{ }_{(\mathrm{aq})}$ adsorption. The reaction was almost instantaneous above $\mathrm{pH}$ 7. In contrast, the reduction rates of $\mathrm{Tc}(\mathrm{VII})$ by DCB-reduced phyllosilicates were not sensitive to $\mathrm{pH}$ or to added $\mathrm{Fe}^{2+}{ }_{\text {(aq) }}$ that adsorbed to the clay. The reduction kinetics were orders of magnitude slower than observed for the Fe(III) oxides, and appeared to be controlled by structural $\mathrm{Fe}(\mathrm{II})$. The following affinity series for heterogeneous $\mathrm{Tc}(\mathrm{VII})$ reduction by $\mathrm{Fe}(\mathrm{II})$ was suggested by the experimental results: aqueous $\mathrm{Fe}(\mathrm{II}) \sim$ adsorbed $\mathrm{Fe}(\mathrm{II})$ in phyllosilicates [ion-exchangeable and some edge-complexed Fe(II)] $\ll$ structural $\mathrm{Fe}(\mathrm{II})$ in phyllosilicates $\ll \mathrm{Fe}$ (II) adsorbed on $\mathrm{Fe}(\mathrm{III})$ oxides. Tc-EXAFS spectroscopy revealed that the reduction products were virtually identical on hematite and goethite that were comprised primarily of sorbed octahedral $\mathrm{TcO}_{2} \mathrm{mono}_{-}$ mers and dimers with significant Fe(III) in the second coordination shell. The nature of heterogeneous Fe(III) resulting from the redox reaction was ambiguous as probed by Tc-EXAFS spectroscopy, although Mössbauer spectroscopy applied to an experiment with ${ }^{56} \mathrm{Fe}$-goethite with adsorbed ${ }^{57} \mathrm{Fe}(\mathrm{II})$ implied that redox product $\mathrm{Fe}(\mathrm{III})$ was goethite-like. The Tc(IV) reduction product formed on the DCB-reduced phyllosilicates was different from the Fe(III) oxides, and was more similar to Tc(IV) oxyhydroxide in its second coordination shell. The heterogeneous reduction of Tc(VII) to less soluble forms by Fe(III) oxideadsorbed $\mathrm{Fe}(\mathrm{II})$ and structural $\mathrm{Fe}(\mathrm{II})$ in phyllosilicates may be an important geochemical process that will proceed at very different rates and that will yield different surface species depending on subsurface $\mathrm{pH}$ and mineralogy.
\end{abstract}

(c) 2008 Elsevier Ltd. All rights reserved.

\section{INTRODUCTION}

${ }^{99}$ Technetium $\left({ }^{99} \mathrm{Tc}\right)$ is a long-lived $\left(t_{1 / 2}=2.13 \times\right.$ $10^{5}$ years) fission product of ${ }^{235}$ uranium, and an important subsurface contaminant at nuclear reprocessing sites (Wildung et al., 1979). Its speciation, solubility and sorption behavior is strongly dependent on its valence state. Under oxic conditions, Tc exists in its most oxidized form as the

\footnotetext{
* Corresponding author. Fax: +1 5093763650 .

E-mail address: tetyana.peretyazhko@pnl.gov (T. Peretyazhko).
}

pertechnetate $\left[\mathrm{TcO}_{4}{ }^{-}\right]$anion which is weakly sorbed under circumneutral and basic $\mathrm{pH}$ conditions (Lieser and Bauscher, 1987; Holta et al., 1992; Wildung et al., 2004). It is consequently highly mobile in groundwaters (Schroeder et al., 1993) and soils with potential for uptake into the food chain as a sulfur analog (Wildung et al., 1979; Bennett and Willey, 2003). The reduced form of technetium, $\mathrm{Tc}(\mathrm{IV})$, is stable in anoxic environments and forms sparingly soluble phases primarily $\mathrm{TcO}_{2} \cdot n \mathrm{H}_{2} \mathrm{O}_{(\mathrm{s})}$ (Bondietti and Francis, 1979; Rard et al., 1999; Wildung et al., 2000).

0016-7037/\$ - see front matter (c) 2008 Elsevier Ltd. All rights reserved. doi:10.1016/j.gca.2008.01.004

This article is a U.S. government work, and is not subject to copyright in the United States. 
The reduction of $\mathrm{Tc}(\mathrm{VII})$ may occur directly through biologic enzymatic pathways (Lloyd et al., 2000; Wildung et al., 2000) and/or indirectly by $\mathrm{Fe}(\mathrm{II})$ and $\mathrm{S}^{2-}$ (Wharton et al., 2000,; Fredrickson et al., 2004; Wildung et al., 2004). The relative importance of these different reduction pathways depends on environmental conditions. For instance, in non-sulfidogenic sediments, Tc(VII) reduction is controlled by reactive $\mathrm{Fe}(\mathrm{II})$ or by direct microbial reduction when $\mathrm{Fe}(\mathrm{II})$ is not present in stoichiometric excess $[\mathrm{Fe}(\mathrm{II}): \mathrm{Tc}(\mathrm{VII})=3: 1$; (Lloyd et al., 2000; Wildung et al., 2004; Burke et al., 2005)]. Ferrous iron is produced in soils, sediments, and subsurface materials by chemical (Stumm and Sulzberger, 1992; Roden, 2004; Szecsody et al., 2004; Anschutz and Penn, 2005; Hyacinthe et al., 2006; Larsen et al., 2006) or biological (Fredrickson et al., 1998; Zachara et al., 1998; Kukkadapu et al., 2001, 2006; Roden, 2004; Komlos et al., 2007; Stucki et al., 2007) reductive dissolution of $\mathrm{Fe}(\mathrm{III})$ (hydr)oxides and/or reduction of phyllosilicate $\mathrm{Fe}(\mathrm{III})$, which exert an important influence on Tc valence speciation.

Iron(II) in anoxic subsurface environments affects the distribution, transport, and biogeochemistry of redox-sensitive chemical contaminants by sorption onto mineral surfaces and by heterogeneous reduction. Sorbed $\mathrm{Fe}$ (II) is a stronger reducing agent than dissolved $\mathrm{Fe}(\mathrm{II})$ (Jolivet et al., 1990; Stumm and Sulzberger, 1992; Haderlein and Pecher, 1999; Liger et al., 1999; Silvester et al., 2005). Iro$\mathrm{n}(\mathrm{II})$ sorbed on various $\mathrm{Fe}(\mathrm{III})$ oxides enhances the reduction rates of nitrite (Sorensen and Thorling, 1991; Hansen et al., 1996; Coby and Picardal, 2005), hexavalent uranium (Liger et al., 1999; Behrends and Van Cappellen, 2005; Jeon et al., 2005), chromate (Buerge and Hug, 1999), and various organic species (Klausen et al., 1995; Charlet et al., 1998; Kim and Picardal, 1999; Amonette et al., 2000; Pecher et al., 2002; Hofstetter et al., 2003; Strathmann and Stone, 2003; Elsner et al., 2004; Gregory et al., 2004; Chun et al., 2006; Colon et al., 2006). The molecular nature and redox properties of surface $\mathrm{Fe}(\mathrm{II})$ responsible for heterogeneous reduction is still under active investigation and debate (e.g., Williams and Scherer, 2004; Silvester et al., 2005). Structural Fe(II) in magnetite, green rusts, and phyllosilicates can also be an effective reductant of redox-sensitive inorganic and organic molecules (Cui and Eriksen, 1996a; Hansen et al., 1996; Hofstetter et al., 2003, 2006). Generalizing the redox reactivity of mineral associated $\mathrm{Fe}(\mathrm{II})$ in surface-complexed, surface-precipitated, and structural states on different mineral phases with different aqueous oxidants has been found to be difficult (e.g., Strathmann and Stone, 2003; Elsner et al., 2004).

The reduction of $\mathrm{Tc}(\mathrm{VII})$ by sorbed or structural $\mathrm{Fe}(\mathrm{II})$ has been observed in reduced sediments (Fredrickson et al., 2004; Wildung et al., 2004), and with mineral sorbents (Cui and Eriksen, 1996a; Cui and Eriksen, 1996b; Lloyd et al., 2000; Pepper et al., 2003). Beyond these studies, heterogeneous reduction has not been systematically investigated to identify the influence of variables such as $\mathrm{pH}$, sorbed $\mathrm{Fe}(\mathrm{II})$ concentration and effective redox potential, and nature of solid surface on $\mathrm{Tc}(\mathrm{VII})$ reduction rate or products. Fredrickson et al. (2004) noted large differences in the heterogeneous reduction rate of $\mathrm{Tc}(\mathrm{VII})$ in a sediment with sig- nificant amounts of $\mathrm{Fe}(\mathrm{III})$ oxides as compared to one dominated by phyllosilicates, but did not identify the primary causes for this behavior. An improved understanding of the geochemical factors controlling heterogeneous reduction is thus necessary to assess the valence stability of Tc in various environments, and for predicting Tc(VII) migration in natural and engineered systems.

This communication extends a recent study of $\mathrm{Tc}(\mathrm{VII})$ reduction by aqueous $\mathrm{Fe}$ (II) (Zachara et al., 2007) to heterogeneous systems. We investigate the rates and extent of heterogeneous $\mathrm{Tc}(\mathrm{VII})$ reduction by sorbed and structural $\mathrm{Fe}(\mathrm{II})$, and identify the nature of reduced, precipitated $\mathrm{Tc}(\mathrm{IV})$-containing reaction products. Key to this investigation was a comparison between heterogeneous Tc(VII) reduction in suspensions of synthetic $\mathrm{Fe}(\mathrm{III})$ oxides with sorbed $\mathrm{Fe}(\mathrm{II})$, with a natural phyllosilicate mixture containing structural $\mathrm{Fe}(\mathrm{II})$ and variable concentrations of ionexchangeable $\mathrm{Fe}(\mathrm{II})$. This comparison revealed that the nature of sorbed and/or structural Fe(II) can have a strong influence on the kinetics and products of heterogeneous $\mathrm{Tc}(\mathrm{VII})$ reduction.

\section{MATERIALS AND METHODS}

\subsection{Kinetic experiments}

All experimental work was performed in a 97\% $\mathrm{Ar} / 3 \%$ $\mathrm{H}_{2}$ atmosphere inside an anaerobic chamber (Forma Scientific, $\mathrm{OH}$ ) that was equipped with a palladium catalyst to remove trace $\mathrm{O}_{2}$. Despite these precautions, it was discovered that the chamber contained up to $4 \times 10^{-7}$ atm $\mathrm{O}_{2}$ [corresponding to $0.29 \mathrm{ppm} \mathrm{O}_{2}$ in the chamber atmosphere (Jeon et al., 2004)]. The presence of this trace amount of $\mathrm{O}_{2}$ resulted in significant oxidation of $\mathrm{Fe}(\mathrm{II})$ in circumneutral $\mathrm{pH}$ solution open to the glove box atmosphere. Consequently, all experiments with $\mathrm{Fe}(\mathrm{II})$ were conducted using a low-temperature oxygen trap described by (Jeon et al., 2004). The $\mathrm{O}_{2}$ trap bottles contained $0.9 \mathrm{mmol} \mathrm{L}^{-1} \mathrm{Fe}(\mathrm{II})$ and $23.3 \mathrm{mmol} \mathrm{L}^{-1} \mathrm{Fe}(\mathrm{III})$ as hydrous ferric oxide (HFO) that was buffered at $\mathrm{pH} 8.1$ with $0.1 \mathrm{~mol} \mathrm{~L}^{-1}$ tris(hydroxymethyl)-aminomethane (TRIS). The half-time for $\mathrm{O}_{2}$ reduction in the suspension phase of the oxygen trap was less than $0.5 \mathrm{~s}$ and the half-time for transfer of $\mathrm{O}_{2}$ from the gas phase within the traps to the water phase was $6 \mathrm{~min}$. The trap lowered $\mathrm{O}_{2}$ concentrations to $<7.5 \times 10^{-9} \mathrm{~atm}$ $\mathrm{O}_{2}$ (Jeon et al., 2004). Using this trap, solutions of Fe(II) could be maintained at $\mathrm{pH} 7$ and 8 for more than 2 weeks without oxidation.

Experiments were conducted in 125 or $200 \mathrm{~mL}$ glass serum reaction bottles (referred to as master reactors). The solution $\mathrm{pH}$ in master reactors was varied from 4 to 7 using $30 \mathrm{mmol} \mathrm{L}^{-1} \mathrm{Na}$-acetate for $\mathrm{pH} 4.0-5.0$, or $30 \mathrm{mmol} \mathrm{L}^{-1}$ PIPES (Na-1,4-piperazine $N, N^{\prime}$-bis 2-ethanesulfonic acid) for $\mathrm{pH}$ 5.5-7.0. Deoxygenated Na-acetate or PIPES buffer solution was added to the master reactors, then the reactors were capped with thick butyl rubber stoppers and crimp sealed. The master reactors were attached to the oxygen trap and deoxygenated. After 4 days of extensive deoxygenation of the reactors, isotopically enriched ${ }^{57} \mathrm{Fe}(\mathrm{II})$ solution was added first and monitored for 2-4 days to ensure stabil- 
Table 1

Summary of experimental conditions and kinetic analyses

\begin{tabular}{|c|c|c|c|c|c|c|c|c|}
\hline & $\mathrm{pH}$ & $\begin{array}{l}\text { Solid } \\
\text { concentration } \\
\left(\mathrm{g} \mathrm{L}^{-1}\right) \\
\end{array}$ & $\begin{array}{l}\mathrm{Tc}(\mathrm{VII})_{\text {added }} \\
\left(\mu \mathrm{mol} \mathrm{L}{ }^{-1}\right)\end{array}$ & $\begin{array}{l}\text { Intrinsic } \mathrm{Fe}(\mathrm{II})^{\mathrm{a}} \\
\left(\mathrm{mmol} \mathrm{L}^{-1}\right)\end{array}$ & $\begin{array}{l}\mathrm{Fe}(\mathrm{II})_{\text {added }} \\
\left(\mathrm{mmol} \mathrm{L}^{-1}\right)\end{array}$ & $\begin{array}{l}\begin{array}{l}\text { Nominal } \\
\text { sorbed Fe (II) } \\
\left(\mathrm{mmol} \mathrm{L}^{-1}\right)\end{array} \\
\end{array}$ & $\begin{array}{l}k_{\mathrm{obs}} \\
\left(\mathrm{h}^{-1}\right)\end{array}$ & $\begin{array}{l}k_{\text {obs }} / \\
\mathrm{Fe}(\mathrm{II})_{\text {sorbed }}\end{array}$ \\
\hline \multirow[t]{9}{*}{ Hematite } & 4.0 & 4.5 & $10.3 \pm 0.1$ & 0 & 0.10 & $0.0052 \pm 0.0004$ & $4 \times 10^{-4}$ & 0.08 \\
\hline & 4.5 & 4.5 & $10.3 \pm 0.1$ & 0 & 0.10 & $0.0049 \pm 0.0002$ & 0.01 & 2.04 \\
\hline & 5.0 & 4.5 & $10.3 \pm 0.1$ & 0 & 0.10 & $0.0102 \pm 0.0004$ & 0.1 & 9.80 \\
\hline & 5.6 & 4.5 & $10.2 \pm 0.0$ & 0 & 0.12 & $0.030 \pm 0.004$ & 6.06 & 202 \\
\hline & 5.8 & 4.5 & $10.2 \pm 0.0$ & 0 & 0.12 & $0.033 \pm 0.001$ & 6.81 & 206 \\
\hline & 6.1 & 4.5 & $10.2 \pm 0.0$ & 0 & 0.12 & $0.038 \pm 0.001$ & 11.91 & 313 \\
\hline & 6.5 & 4.5 & $10.2 \pm 0.0$ & 0 & 0.10 & $0.038 \pm 0.002$ & 15.14 & 398 \\
\hline & 7.0 & 4.5 & $10.3 \pm 0.0$ & 0 & 0.12 & $0.070 \pm 0.002$ & $>16.0$ & $>228$ \\
\hline & 7.0 & 9.0 & $20.5 \pm 0.0$ & 0 & 0.23 & $0.160 \pm 0.007$ & $>16.0$ & $>100$ \\
\hline \multirow[t]{2}{*}{ Goethite } & 7.0 & 1.5 & $10.3 \pm 0.0$ & 0 & 0.12 & $0.078 \pm 0.001$ & $>16.0$ & $>205$ \\
\hline & 7.0 & 3.0 & $20.5 \pm 0.0$ & 0 & 0.23 & $0.169 \pm 0.002$ & $>16.0$ & $>94$ \\
\hline \multirow{5}{*}{ FRC-dcb } & 6.0 & 10.0 & $10.0 \pm 0.2$ & $0.114 \pm 0.023$ & 0 & 0 & 0.19 & \\
\hline & 6.5 & 10.0 & $10.3 \pm 0.0$ & $0.100 \pm 0.014$ & 0 & 0 & 0.15 & \\
\hline & 7.0 & 20.0 & $10.2 \pm 0.1$ & $0.154 \pm 0.027$ & 0 & 0 & 0.15 & \\
\hline & 7.0 & 10.0 & $10.1 \pm 0.0$ & $0.093 \pm 0.003$ & 0.10 & $0.094 \pm 0.006$ & 0.18 & 1.91 \\
\hline & 7.0 & 20.0 & $10.1 \pm 0.0$ & $0.183 \pm 0.014$ & 0.20 & $0.198 \pm 0.012$ & 0.19 & 0.96 \\
\hline \multirow[t]{3}{*}{$\mathrm{FRC}-\mathrm{dcb}-\mathrm{HCl}$} & 7.0 & 20.0 & $10.6 \pm 0.0$ & 0 & 0 & 0 & $\mathrm{nr}^{\mathrm{c}}$ & \\
\hline & 7.0 & 10.0 & $10.4 \pm 1.2$ & 0 & 0.10 & 0 & $\mathrm{nr}$ & \\
\hline & 7.0 & 20.0 & $20.7 \pm 0.0$ & 0 & 0.20 & 0 & $\mathrm{nr}$ & \\
\hline
\end{tabular}

${ }^{a}$ Experimentally determined by $2 \mathrm{~h} 0.5-\mathrm{mol} \mathrm{L}^{-1} \mathrm{HCl}$ extraction.

${ }^{\mathrm{b}}$ Difference in dissolved $\mathrm{Fe}(\mathrm{II})$ concentration before and after sorbent spiking.

${ }^{\mathrm{c}}$ No reduction.

ity against oxidation or precipitation. Solid [Fe(III) oxide or phyllosilicate isolate] was added and 2 days equilibration time was allowed for $\mathrm{Fe}(\mathrm{II})$ adsorption. The suspensions were continuously and gently stirred using a Teflon-coated magnetic stirring bar. Tc(VII) was added to the master reactors after $\mathrm{Fe}(\mathrm{II})$ had reached adsorption equilibrium. Dissolved Fe(II), total Fe(II) and dissolved Tc(VII) concentrations were monitored from this point onward. The conditions of the reduction experiments are summarized in Table 1. The Tc(VII) aqueous concentrations used (10$20 \mu \mathrm{mol} \mathrm{L}{ }^{-1}$ ) were within the range of those observed in porewaters of Hanford's BC-crib complex (Serne and Mann, 2004; Ward et al., 2004) where over 400 Ci were released to the vadose zone.

\subsection{Solid phases}

Synthetic medium surface area $\left(55 \mathrm{~m}^{2} \mathrm{~g}^{-1}\right.$ by $\mathrm{N}_{2}$-BET analysis) goethite $(\alpha-\mathrm{FeOOH})$ was produced by adjusting $0.4 \mathrm{~mol} \mathrm{~L}^{-1} \mathrm{FeCl}_{3} \cdot 6 \mathrm{H}_{2} \mathrm{O}$ solution to $\mathrm{pH} 13$ with $4 \mathrm{~mol} \mathrm{~L}^{-1}$ $\mathrm{NaOH}$ and incubating the suspension at $70{ }^{\circ} \mathrm{C}$ for $16 \mathrm{~h}$ (Schwertmann and Cornell, 2000). The goethite was washed by centrifugation until the $\mathrm{Cl}^{-}$concentration was $<0.5 \mathrm{mmol} \mathrm{L}^{-1}$, freeze-dried, and then passed through a $100-\mu \mathrm{m}$ sieve. Hematite $\left(\alpha-\mathrm{Fe}_{2} \mathrm{O}_{3}\right)$ was purchased from J.T. Baker and had a specific surface area of $9 \mathrm{~m}^{2} \mathrm{~g}^{-1}$ by $\mathrm{N}_{2}$-BET method and average particle diameter of $1.0 \mu \mathrm{m}$ as determined by SEM particle counting.

A weathered shale-limestone saprolite (designated FRC) was obtained from the U.S. Department of Energy's (DOE) Environmental Remediation Sciences Division
(ERSD) Field Research Center (FRC) background site located in West Bear Creek Valley of DOE's Oak Ridge Site in eastern Tennessee. The FRC sample was air-dried and passed through a 2-mm sieve. The surface area measured by $\mathrm{N}_{2}$-BET method was $32 \mathrm{~m}^{2} \mathrm{~g}^{-1}$.

The FRC sediment was treated with dithionite-citratebicarbonate (DCB; Stucki et al., 1984; Hofstetter et al., 2003) to reduce and remove $\mathrm{Fe}(\mathrm{III})$ and $\mathrm{Mn}$ (III/IV) oxides. This treatment yielded a natural phyllosilicate mixture with $\mathrm{Fe}(\mathrm{II} / \mathrm{III})$ ratio significantly higher than the pristine sediment (Kukkadapu et al., 2006). A portion of DCB-treated FRC was further treated with $0.5 \mathrm{~mol} \mathrm{~L}^{-1} \mathrm{HCl}$ for $2 \mathrm{~h}$. The weak-acid extraction partially remove $\mathrm{Fe}(\mathrm{II})$ from some reduced phyllosilicates (Kukkadapu et al., 2006), presumably from the smallest phyllosilicate size fraction of FRC (e.g., $<0.2 \mu \mathrm{m}$ ) and edge-complexed Fe(II) (Hofstetter et al., 2003, 2006). All subsequent manipulations of the reduced phyllosilicates were performed in a controlled atmosphere glove box. The DCB-treated FRC (FRC-dcb) and DCB$0.5 \mathrm{~mol} \mathrm{~L}^{-1} \mathrm{HCl}$-treated FRC (FRC-dcb-HCl) materials were washed extensively with anoxic distilled and ionized water (ADDW) to solubilize residual extractant and bicarbonate until the conductivities of the final centrifuges were $\sim 10 \mu \mathrm{mho} \mathrm{cm}^{-1}$. The FRC-dcb suspension was then washed $3 \times$ with anoxic $0.5 \mathrm{~mol} \mathrm{~L}^{-1} \mathrm{CaCl}_{2}$ to displace ion-exchangeable Fe(II) (Charlet and Tournassat, 2005), and then a final $3 \times$ with anoxic $30 \mathrm{mmol} \mathrm{L}^{-1}$ PIPES buffer at $\mathrm{pH} 7$ to partially remove edge-complexed $\mathrm{Fe}(\mathrm{II})$. The FRC-dcb- $\mathrm{HCl}$ was treated identically to yield suspensions with the same initial condition. Subsequent analyses of the FRC-dcb showed that it contained a particle size distribu- 
tion (by hydrometer method) of $24 \%$ sand, $43 \%$ silt, and $33 \%$ clay; a cation exchange capacity of $551 \mu$ equiv $\mathrm{g}^{-1}$ (by ammonium chloride extraction), and a surface area of $19 \mathrm{~m}^{2} \mathrm{~g}^{-1}$ (by $\mathrm{N}_{2}$-BET analysis).

All solid materials were suspended in either 30 mmol L ${ }^{-1} \mathrm{Na}$-acetate at $\mathrm{pH} 5.0$ or PIPES at pH 7.0 buffer solutions to obtain final concentrations of $200 \mathrm{~g} \mathrm{~L}^{-1}$ hematite, $50 \mathrm{~g} \mathrm{~L}^{-1}$ goethite, or $400 \mathrm{~g} \mathrm{~L}^{-1}$ FRC-dcb and $\mathrm{FRC}-\mathrm{dcb}-\mathrm{HCl}$. The suspensions were prepared in serum bottles, capped with thick butyl rubber stoppers, crimp sealed, and degassed using the oxygen trap in the anoxic chamber.

\subsection{Analytical techniques}

Syringes, needles, glass vials, and plastic tubes were used for sample processing. All glassware and plastic bottles were acid washed with $1 \% \mathrm{HNO}_{3}$, rinsed several times with distilled and deionized water (DDW), and purged with $\mathrm{O}_{2}$ free $\mathrm{Ar} / \mathrm{H}_{2}$ before use.

All chemicals were reagent grade or better, unless otherwise described. ADDW was stored in the anoxic chamber for preparation of all solutions and suspensions. ${ }^{99}$ Technetium was purchased as $\mathrm{NH}_{4} \mathrm{TcO}_{4}$ (Perkin-Elmer Life Sciences Inc., Boston, MA) and diluted in ADDW to produce a $5-\mathrm{mmol} \mathrm{L}^{-1}$ stock solution. All stock solutions and acids/bases were stored in serum bottles that were extensively deoxygenated using the oxygen trap before the addition to the master reactors. All samples that contained $\mathrm{Fe}(\mathrm{II})$ were kept inside the chamber at all times.

For dissolved $\mathrm{Fe}(\mathrm{II})$ analysis, samples were filtered $(0.2 \mu \mathrm{m})$ and $0.1-0.5 \mathrm{~mL}$ of the filtrate was added to $5 \mathrm{~mL}$ ferrozine reagent $\left(1 \mathrm{~g} \mathrm{~L}^{-1}\right.$ ferrozine in $50 \mathrm{mmol} \mathrm{L}^{-1}$ HEPES buffer, $\mathrm{pH}$ 7.0) in the anaerobic chamber. After $15 \mathrm{~min}$, the samples were removed and the absorbance at $562 \mathrm{~nm}$ was determined with a Shimadzu UV-1240 spectrophotometer. Total $\mathrm{Fe}(\mathrm{II})$ was determined by adding a $1.5-\mathrm{mL}$ aliquot of suspension to $1.5 \mathrm{~mL}$ of $1 \mathrm{~mol} \mathrm{~L}^{-1} \mathrm{HCl}$. The sample was then extracted for $2 \mathrm{~h}$ in the anaerobic chamber. The samples were filtered $(0.2 \mu \mathrm{m})$ and analyzed using the ferrozine method. Samples for dissolved Tc(VII) were filtered $(0.2 \mu \mathrm{m})$ and $1 \mathrm{~mL}$ of the filtrate was added to $9 \mathrm{~mL}$ anoxic scintillation cocktail in the anaerobic chamber. Radioanalysis was performed with a Packard 2500TR liquid scintillation counter (Packard Instrument Co., Meriden, CT, USA); the minimum quantifiable $\mathrm{Tc}_{\mathrm{aq}}$ concentration was $5.9 \pm 0.24 \times 10^{-9} \mathrm{~mol} \mathrm{~L}^{-1}$ (Zachara et al., 2007). Solution $\mathrm{pH}$ was measured using an Orion $250 \mathrm{~A}+\mathrm{pH}$ meter with a combination $\mathrm{pH} /$ temperature probe.

\subsection{X-ray absorption (XAS) spectroscopy}

\subsubsection{Mineral, valence, and speciation standards}

$\mathrm{TcO}_{2} \cdot n \mathrm{H}_{2} \mathrm{O}$ precipitate was prepared by the reduction of $\mathrm{Tc}(\mathrm{VII})$ to $\mathrm{Tc}(\mathrm{IV})$ using sodium ditihionite $\left(\mathrm{Na}_{2} \mathrm{~S}_{2} \mathrm{O}_{4}\right)$ inside a controlled atmospheric chamber (Hess et al., 2004). To reduce the $\mathrm{Tc}(\mathrm{VII})$ using the desired reductant to $\mathrm{Tc}(\mathrm{VII})$ ratio, $0.18 \mathrm{~mL}$ of $0.29 \mathrm{~mol} \mathrm{~L}^{-1} \mathrm{Tc}(\mathrm{VII})$ was added to $4.12 \mathrm{~mL}$ of $0.195 \mathrm{~mol} \mathrm{~L}^{-1} \mathrm{Na}_{2} \mathrm{~S}_{2} \mathrm{O}_{4}$. The $\mathrm{pH}$ was then adjusted to 12 using $\mathrm{NaOH}$. A black precipitate quickly formed which was aged for $72 \mathrm{~h}$. The precipitate was then washed $3 \times$ using $20 \mathrm{~mL}$ freshly prepared $0.01 \mathrm{~mol} \mathrm{~L}^{-1}$ $\mathrm{Na}_{2} \mathrm{~S}_{2} \mathrm{O}_{4}$ and then ADDW. The remaining solid was collected by filtration and then dried in an oxygen-scrubbed dessicator in the glove box.

A stock suspension of ferrihydrite was prepared according to Schwertmann and Cornell (2000). The ferrihydrite suspension was allowed to remain for $48 \mathrm{~h}$ inside the chamber. Excess $\mathrm{Na}^{+}$and $\mathrm{NO}_{3}{ }^{-}$were removed from the ferrihydrite by dialysis in DDW. The ferrihydrite concentration was determined by gravimetric and $\mathrm{Fe}$ analyses. Aliquots were dried under anoxic conditions for XAS standards yielding 5-6 line ferrihydrite according to X-ray diffraction analysis.

A subsample of the $\mathrm{TcO}_{2} \cdot n \mathrm{H}_{2} \mathrm{O}$ precipitate $(20 \mathrm{mg}$ of ${ }^{99} \mathrm{Tc}$ ) was added to $900 \mathrm{~mL}$ of $2 \mathrm{~mol} \mathrm{~L}^{-1} \mathrm{HCl}$ and allowed to dissolve to steady state. The Tc(IV) solution was filtered through a $0.45-\mu \mathrm{m}$ filter under anoxic conditions and the ${ }^{99} \mathrm{Tc}$ concentration quantified in the filtrate. A Tc(IV)-ferrihydrite coprecipitate reference phase with $1 \mathrm{~mol} \% \mathrm{Tc}(\mathrm{IV})$ was prepared by mixing a predetermined volume of acidic $\mathrm{Tc}(\mathrm{IV})$ solution with an appropriate volume of ferrihydrite suspension; this mixing lead to the dissolution of all of the ferrihydrite. The acidic $\mathrm{Tc}(\mathrm{IV}) / \mathrm{Fe}$ (III) solution was then adjusted to $\mathrm{pH} 7(<1 \mathrm{~h})$ to form the coprecipitate. The resulting solid was aged for $2 \mathrm{~h}$, washed with ADDW, and dried under strictly anoxic conditions. The dried solid yielded an X-ray diffraction pattern of 2-line ferrihydrite with traces of a 6-line structure.

Technetium(IV)-hematite and Tc(IV)-goethite reference phases were prepared by mixing aliquots of the above described, standard Tc(IV) solution with hematite or goethite stock suspensions in ADDW to obtain final concentrations of $\sim 10 \mu \mathrm{mol} \mathrm{L}{ }^{-1} \mathrm{Tc}(\mathrm{IV}), 4.5 \mathrm{~g} \mathrm{~L}^{-1}$ hematite and $1.5 \mathrm{~g} \mathrm{~L}^{-1}$ goethite in $0.5 \mathrm{~mol} \mathrm{~L}^{-1} \mathrm{HCl}$. This procedure was mandated by the solubility of $\mathrm{TcO}_{2} \cdot n \mathrm{H}_{2} \mathrm{O}$ which does not increase above $10^{-8} \mathrm{~mol} \mathrm{~L}^{-1}$ until $\mathrm{pH}<2$. The suspension $\mathrm{pH}$ was then adjusted to $\mathrm{pH} 7.0-7.7$ by $10 \mathrm{~mol} \mathrm{~L}^{-1} \mathrm{NaOH}$ (2030 min titration). The time that goethite and hematite experienced $\mathrm{pH}<3$ was estimated to be $5-15 \mathrm{~min}$, with the possibility of some dissolution to yield $\mathrm{Fe}(\mathrm{III})_{\mathrm{aq}}$ (Jang et al., 2007). The resulting solids were aged for 4 days, washed $4 \times$ with $30 \mathrm{mmol} \mathrm{L}^{-1}$ PIPES buffer at $\mathrm{pH} 7$ and dried in an oxygen-scrubbed dessicator in the glove box.

\subsubsection{Sample preparation}

The four post-reaction mineral suspensions [FRC-dcb at $10 \mathrm{~g} \mathrm{~L}^{-1}$ and $\mathrm{pH} 6$ contacted with $10 \mu \mathrm{mol} \mathrm{L}{ }^{-1} \mathrm{Tc}(\mathrm{VII})$ (FRC-dcb1); FRC-dcb at $10 \mathrm{~g} \mathrm{~L}^{-1}$ and $\mathrm{pH} 6.5$ contacted with $10 \mu \mathrm{mol} \mathrm{L}^{-1} \mathrm{Tc}(\mathrm{VII}) \quad$ (FRC-dcb2); goethite at $3 \mathrm{~g} \mathrm{~L}^{-1}$ and $\mathrm{pH} 7$ contacted with $0.2 \mathrm{mmol} \mathrm{L}^{-1} \mathrm{Fe}(\mathrm{II})$ and $20 \mu \mathrm{mol} \mathrm{L}^{-1} \mathrm{Tc}(\mathrm{VII})$; and hematite at $9 \mathrm{~g} \mathrm{~L}^{-1}$ and $\mathrm{pH} 7$ contacted with $0.2 \mathrm{mmol} \mathrm{L}^{-1} \mathrm{Fe}(\mathrm{II})$ and $20 \mu \mathrm{mol} \mathrm{L}^{-1}$ $\mathrm{Tc}(\mathrm{VII})]$ were transferred to $50 \mathrm{~mL}$ Oak Ridge polycarbonate screw capped centrifuge tubes. The samples were centrifuged at $2000 \mathrm{rcf}$ for $20 \mathrm{~min}$, and the supernatant discarded. The solid was washed with $10-15 \mathrm{~mL}$ of degassed, anhydrous methanol. The samples were dried in a vacuum dessicator with Drierite, ground and packed in a Teflon sample cell with a slot $2 \mathrm{~mm} \times 10 \mathrm{~mm} \times 2 \mathrm{~mm}$. Kapton adhesive 
tape (1 mil, CS Hyde, Co.) was applied to one side of the holder to make a recess into which the sample was packed. Kapton tape was applied to the top of the holder. A second layer of Kapton tape was applied to seal the sample into the holder. The sample holder was sealed inside a Kapton envelope made from 2 mil Kapton film (CS Hyde Co.). The samples within the Kapton envelopes were placed inside $100 \mathrm{~mL}$ Wheaton glass bottles that were sealed with special plastic stoppers designed for anaerobic use for storage and shipment to the beamline.

\subsubsection{XAS methods}

Tc-extended X-ray adsorption fine structure (Tc-EXAFS) measurements were made at the Advanced Photon Source (APS) sector 20 beamlines 20-ID and 20-BM in fluorescence mode using a multi-element Ge fluorescence detector. A total of 10-20 scans were run for each of the four samples on 20-ID. The Tc(IV)-ferrihydrite, hematite and goethite standards were run on 20-BM. A Mo foil was used for energy calibration. A Si(1 111$)$ monochromator was used with a $1-\mathrm{mm}$ entrance slit located approximately $50 \mathrm{~m}$ from the source on both beamlines. The monochrometer provided an energy resolution of about $4 \mathrm{eV}$ at the Tc edge. At the beamline, the reduced samples were kept in a plastic container with Kapton windows under flowing nitrogen to avoid any oxygen diffusion through the Kapton of the sample cells.

The EXAFS and XANES data were analyzed using the Athena and Artemis interfaces to the IFEFFIT program package (Ravel and Newville, 2005). Theoretical models were calculated using FEFF 7 (Rehr and Albers, 2000) with the parameters refined using ARTEMIS.

\section{5. ${ }^{57} \mathrm{Fe}$ Mössbauer spectroscopy}

Mössbauer spectroscopy was performed on the FRCdcb sediment before and after $\mathrm{HCl}$ extraction according to procedures outlined in Kukkadapu et al. (2006).

Mössbauer spectroscopy is a ${ }^{57} \mathrm{Fe}$ (natural abundance of $2.12 \%$ ) specific technique. Therefore, to probe the nature of adsorbed $\mathrm{Fe}(\mathrm{II})$, measurements were performed on ${ }^{56} \mathrm{Fe}-$ goethite (Mössbauer insensitive nucleus) with adsorbed ${ }^{57} \mathrm{Fe}(\mathrm{II})$ before and after reaction with $\mathrm{Tc}(\mathrm{VII})$. Isotopically enriched ${ }^{57} \mathrm{Fe}(\mathrm{II})$ and ${ }^{56} \mathrm{Fe}(\mathrm{II})$ stock solutions were prepared in $0.1 \mathrm{~mol} \mathrm{~L}^{-1} \mathrm{HCl}$ from $96.7 \%$ pure ${ }^{57} \mathrm{Fe}(0)$ and 99.94 pure ${ }^{56} \mathrm{Fe}(0)$ metals (Web Research Co., MN) following the procedure of Williams and Scherer (2004). Oxidation of the ${ }^{56} \mathrm{Fe}(\mathrm{II})$ acid solution was achieved by $\mathrm{H}_{2} \mathrm{O}_{2}$ addition. Goethite was synthesized from a ${ }^{56} \mathrm{Fe}(\mathrm{III})$ solution mixed with $5 \mathrm{~mol} \mathrm{~L}^{-1} \mathrm{KOH}$ and diluted with DD water (Williams and Scherer, 2004). The precipitate obtained was incubated at $70{ }^{\circ} \mathrm{C}$ for three days for transformation to goethite. The resulting goethite had a specific surface area of $41 \mathrm{~m}^{2} \mathrm{~g}^{-1}$ by $\mathrm{N}_{2}$-BET method. Scanning electron microscopy showed the presence of $500 \mathrm{~nm}$ acicular crystals. Suspensions $\left[1.5 \mathrm{~g} \mathrm{~L}^{-1}{ }^{56} \mathrm{Fe}\right.$-goethite, $0.1 \mathrm{mmol} \mathrm{L}{ }^{-1}{ }^{57} \mathrm{Fe}(\mathrm{II}), 30 \mathrm{mmol} \mathrm{L}^{-1}$ PIPES, pH 7 with/ without $\left.10 \mu \mathrm{mol} \mathrm{L}{ }^{-1} \mathrm{Tc}(\mathrm{VII})\right]$ were prepared as described in the Sections 2.1 and 2.2. Two days of equilibration with ${ }^{57} \mathrm{Fe}(\mathrm{II})$ were allowed before collecting the Mössbauer sam- ple. The remaining suspension was spiked with $\mathrm{Tc}(\mathrm{VII})$ stock solution and allowed to react for 10 days.

The goethite Mössbauer samples were prepared by withdrawing $50 \mathrm{~mL}$ of suspension from the master reactor. A disposable syringe filter holder (Swinnex) with a removable filter $[0.45 \mu \mathrm{m}$ pore-size (Millipore); $1.25 \mathrm{~cm}$ diameter] was used. A $\mathrm{Cu}$ Mössbauer sample holder $(0.95 \mathrm{~cm}$ by $1.27 \mathrm{~cm}$ ) that was sealed at one end with clear scotch tape was half-filled with the vaseline. The filter membrane containing the precipitate was placed on top of the vaseline within the Mössbauer sample holder, the holder was then filled with vaseline and sealed with scotch tape. An oxygen impermeable polymer (aluminized Mylar stable to $4 \mathrm{~K}$ ) was used as an outer seal on both ends of the holder. The tape and polymer were snapped into the holder with rings made of carbonized-polyethyletherketone (PEEK) polymer. The sample holders were stored in the anoxic chamber until analysis.

Mössbauer spectra for both the FRC-dcb samples and ${ }^{57} \mathrm{Fe} /{ }^{56} \mathrm{Fe}$ goethite were collected using a $50-\mathrm{mCi}$ (initial strength) ${ }^{57} \mathrm{Co} / \mathrm{Rh}$ source. The velocity transducer MVT1000 (WissEL) was operated in a constant acceleration mode $\left(23 \mathrm{~Hz}, \pm 12 \mathrm{~mm} \mathrm{~s}^{-1}\right)$. An Ar-Kr proportional counter was used to detect the radiation transmitted through the holder, and the counts were stored in a multichannel scalar (MCS) as a function of energy (transducer velocity) using a 1024 channel analyzer. Data were folded to 512 channels to give a flat background and a zero-velocity position corresponding to the center shift (CS or $\delta$ ) of a metal iron foil at room temperature. Calibration spectra were obtained with a $25-\mu \mathrm{m}$-thick $\alpha-\mathrm{Fe}(\mathrm{m})$ foil (Amersham, England) placed in the same position as the samples to minimize any errors due to changes in geometry. A closed-cycle cryostat (ARS, Allentown, PA) was employed for 260, 77 and $10 \mathrm{~K}$ measurements. The Mössbauer data were modeled with the Recoil software using a Voight-based structural filtering routine (Rancourt and Ping, 1991).

\section{RESULTS}

\subsection{Reactivity of sorbed $\mathrm{Fe}(\mathrm{II})$ on goethite and hematite}

\subsubsection{Kinetic behavior}

Technetium(VII) was weakly adsorbed by Fe(III) oxides in buffered solution when $\mathrm{Fe}$ (II) was absent (data not shown). We found that the sorption of $10 \mu \mathrm{mol} \mathrm{L}^{-1}$ $\mathrm{TcO}_{4}{ }^{-}$was less than $3 \%$ to $4.5 \mathrm{~g} \mathrm{~L}^{-1}$ hematite even at $\mathrm{pH}$ 5.6, where significant positive charge density existed.

The experiments were designed to minimize the effect of homogeneous $\mathrm{Tc}(\mathrm{VII})$ reduction by dissolved $\mathrm{Fe}(\mathrm{II})$ as a parallel reaction pathway. The rates of homogeneous $\mathrm{Tc}(\mathrm{VII})$ reduction are influenced by $\mathrm{Fe}(\mathrm{II})$ concentration and $\mathrm{pH}$ (Zachara et al., 2007). Our previous experiments showed that less than $3 \%$ of $\mathrm{Tc}$ (VII) was homogeneously reduced after 5 days reaction time (i.e., the pseudo-first-order rate constant was $0.005 \mathrm{day}^{-1}$ ) when $11 \mu \mathrm{mol} \mathrm{L}-1$ of $\mathrm{Tc}(\mathrm{VII})$ was reacted with $0.05 \mathrm{mmol} \mathrm{L}^{-1}$ of $\mathrm{Fe}(\mathrm{II})$ at $\mathrm{pH} 7$ in $10 \mathrm{mmol} \mathrm{L}^{-1}$ PIPES solution. Based on these past observations, the dissolved $\mathrm{Fe}(\mathrm{II})$ concentrations in the heterogeneous experiments were generally maintained at $\leqslant 0.05$ 
a

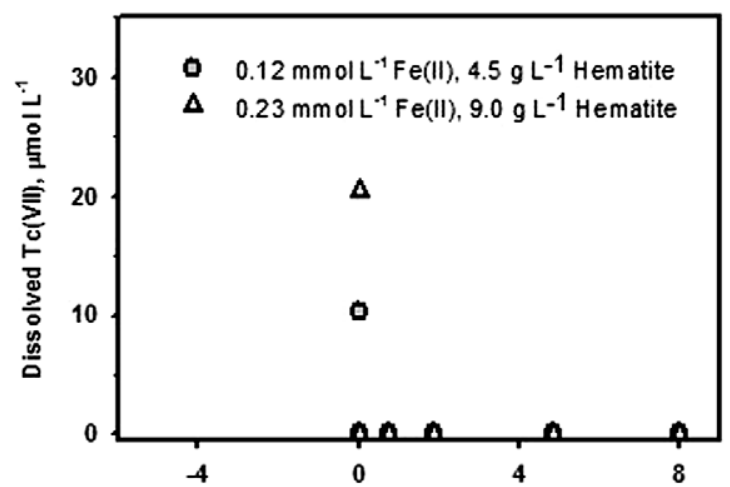

b

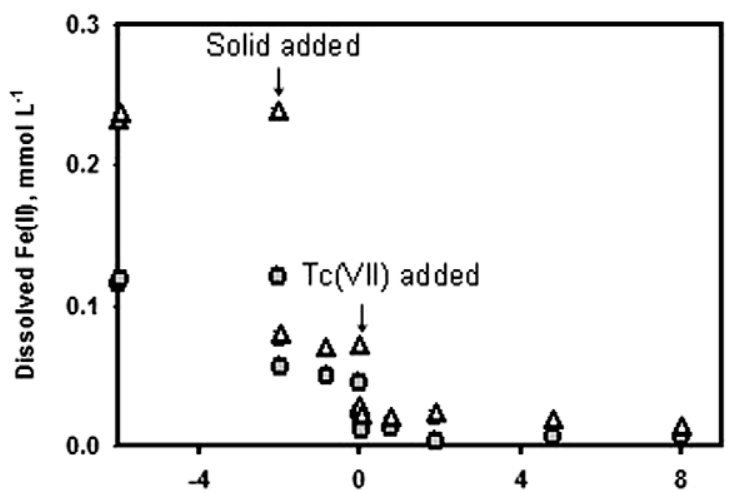

C

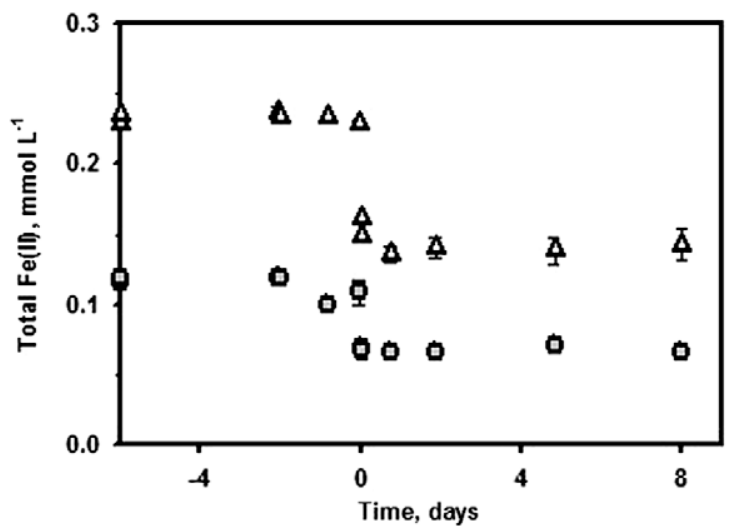

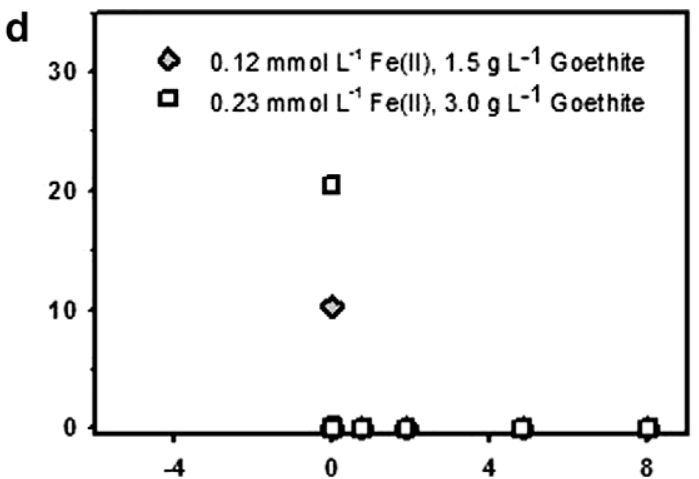
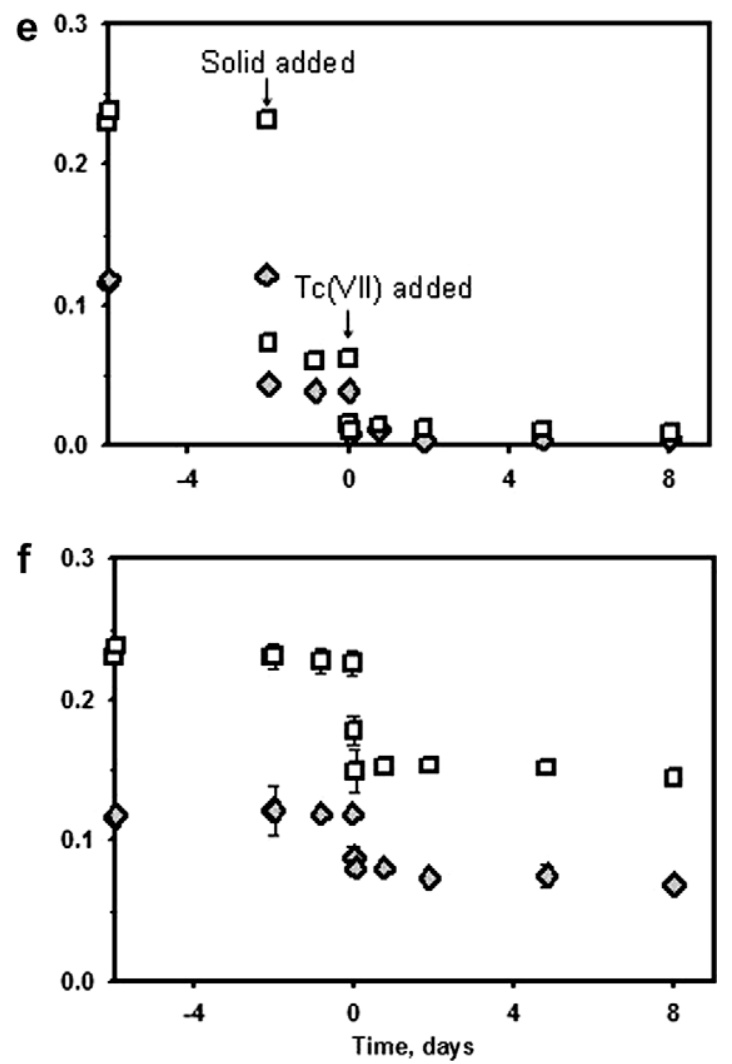

Fig. 1. Time-dependent behavior of $\mathrm{Fe}^{2+}$ (aq) solutions spiked sequentially with hematite or goethite (at day -2 , concentrations noted) and $\mathrm{Tc}$ (VII) (20 or $10 \mu \mathrm{mol} \mathrm{L}{ }^{-1}$ at day 0 , concentrations noted) for $\mathrm{pH} 7$ : (a) dissolved Tc(VII) with hematite, (b) dissolved Fe(II) with hematite, (c) total $\mathrm{Fe}(\mathrm{II})$ with hematite, (d) dissolved $\mathrm{Tc}(\mathrm{VII})$ with goethite, (e) dissolved $\mathrm{Fe}(\mathrm{II})$ with goethite, and (f) total Fe(II) with goethite. Data represent means $( \pm \mathrm{SD})$ of triplicate samples.

mmol L ${ }^{-1}$ [after adsorptive pre-equilibration of $\mathrm{Fe}(\mathrm{II})$ with the sorbent of interest]. Up to $0.09 \mathrm{mmol} \mathrm{L}^{-1}$ of dissolved $\mathrm{Fe}(\mathrm{II})$ was allowed in the suspensions with lower $\mathrm{pH}$ (between 5.6 and 6.5) where little homogeneous $\mathrm{Tc}(\mathrm{VII})$ reduction was observed even in the presence of $0.4 \mathrm{mmol} \mathrm{L}^{-1}$ dissolved Fe(II) (Zachara et al., 2007).

The heterogeneous reduction of $\mathrm{Tc}(\mathrm{VII})$ to $\mathrm{Tc}(\mathrm{IV})$ was virtually instantaneous when 10 or $20 \mu \mathrm{mol} \mathrm{L}^{-1}$ of $\mathrm{Tc}$ (VII) was reacted in suspensions containing 0.12 or $0.23 \mathrm{mmol} \mathrm{L}^{-1}$ total $\mathrm{Fe}(\mathrm{II})$ and $\mathrm{Fe}(\mathrm{III})$ oxides at $\mathrm{pH} 7$ (Fig. 1a and d), even though Tc(VII) adsorption to these phases in the absence of $\mathrm{Fe}(\mathrm{II})$ was not measureable. The adsorbed $\mathrm{Fe}(\mathrm{II})$ concentration in these experiments (Table
1) ranged from $0.08 \mathrm{mmol} \mathrm{L}^{-1}$ [for $0.12 \mathrm{mmol} \mathrm{L}^{-1} \mathrm{Fe}(\mathrm{II})$ тот] to $0.17 \mathrm{mmol} \mathrm{L}^{-1}$ [for $0.23 \mathrm{mmol} \mathrm{L}^{-1} \mathrm{Fe}(\mathrm{II})_{\mathrm{TOT}}$. These adsorption densities correspond to 2.75 times the stoichiometric demand for complete reduction of added $\mathrm{Tc}(\mathrm{VII})$ to $\mathrm{Tc}(\mathrm{IV})$, given the differences in initial $\mathrm{Tc}(\mathrm{VII})$ concentration. The complete stability of $\mathrm{Fe}(\mathrm{II})$ before sorbent addition (from -6 to -2 days) confirmed that the experimental systems were strictly anoxic (Fig. 1c and f). The addition of hematite and goethite to the $\mathrm{Fe}$ (II) containing solutions caused a small decrease in $0.5 \mathrm{~mol} \mathrm{~L}^{-1} \mathrm{HCl}$ recoverable total $\mathrm{Fe}(\mathrm{II})$ after 2 days of reaction time (Fig. 1c and f). This observation was consistent with previous studies (Jeon et al., 2001, 2003) that suggest surface 
a

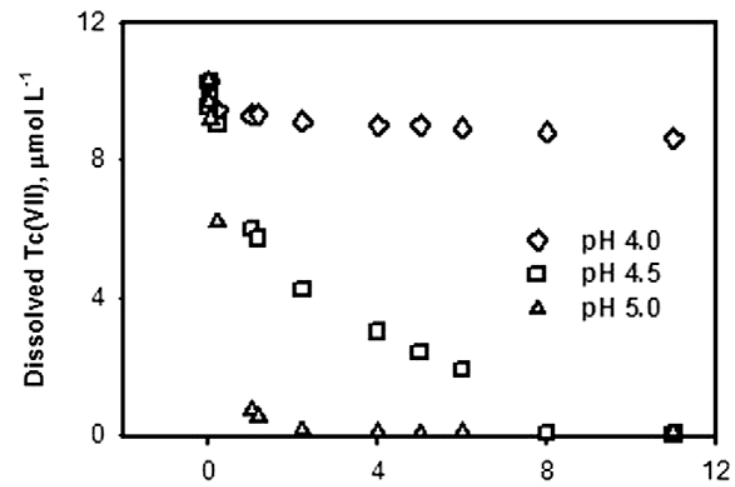

b

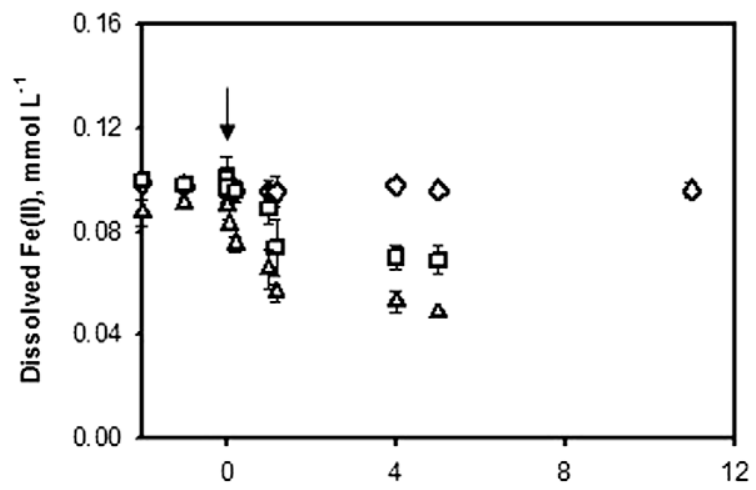

C

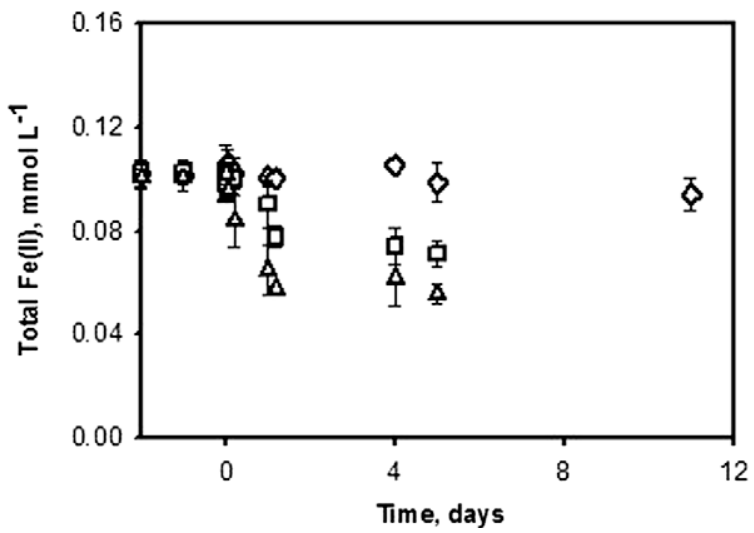

d

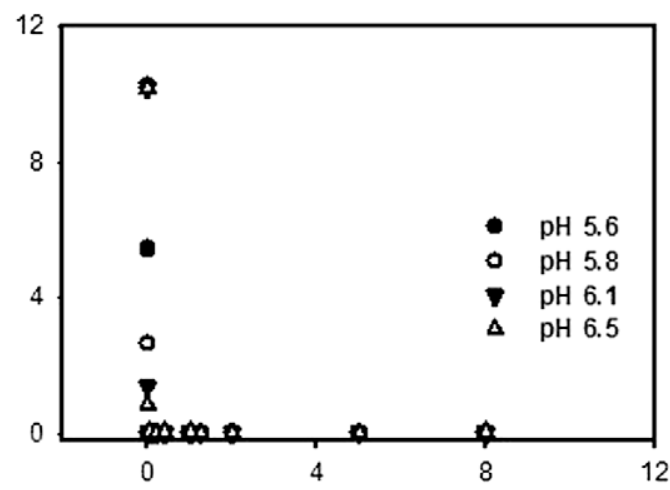

e 0
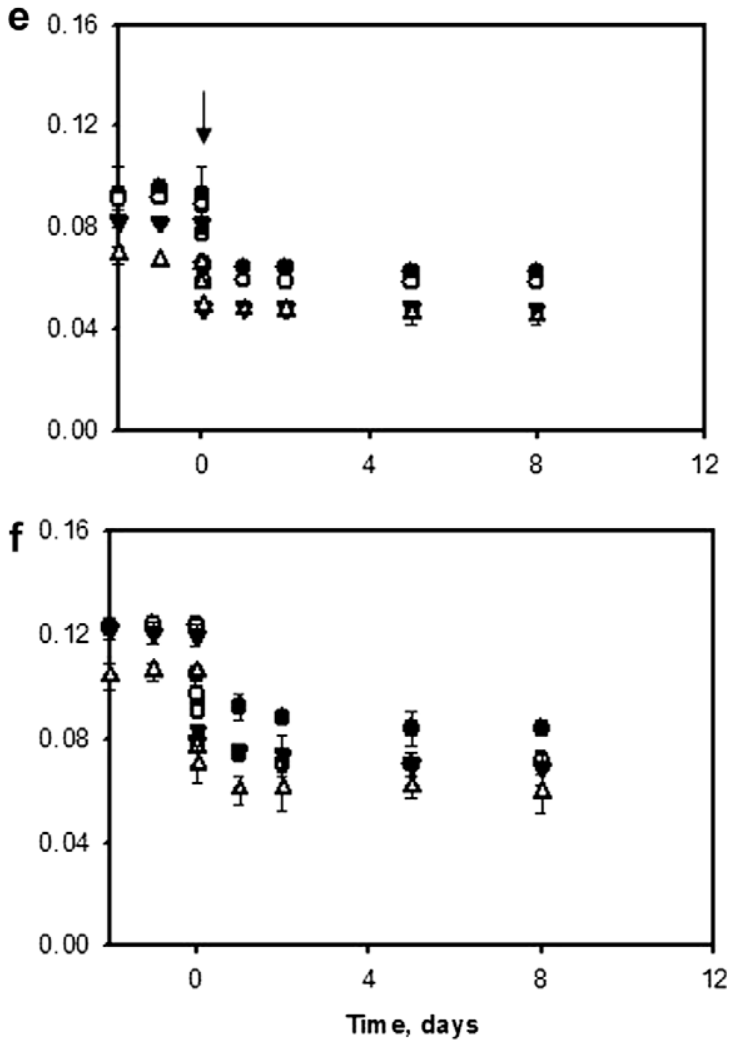

Fig. 2. Time-dependent behavior of $\mathrm{Fe}^{2+}{ }_{\text {aq) }}$-hematite suspensions at various $\mathrm{pH}$ values (as noted) that were spiked with $10 \mu \mathrm{mol} \mathrm{L}^{-1} \mathrm{Tc}(\mathrm{VII})$ at day 0: (a) dissolved Tc(VII), (b) dissolved $\mathrm{Fe}(\mathrm{II})$, and (c) total $\mathrm{Fe}(\mathrm{II})$ at $\mathrm{pH} 4.0,4.5$, and 5.0, and (d) dissolved $\mathrm{Tc}(\mathrm{VII})$, (e) dissolved Fe(II), and (f) total $\mathrm{Fe}(\mathrm{II})$, at $\mathrm{pH}=5.6,5.8,6.1$, and 6.5. Data represent means $( \pm \mathrm{SD})$ of triplicate samples.

phase formation initiated by interfacial electron transfer from sorbed $\mathrm{Fe}(\mathrm{II})$ to $\mathrm{Fe}(\mathrm{III})$ in bulk hematite or goethite. Both total and dissolved Fe(II) concentrations dropped sharply within a minute after the Tc(VII) addition (Fig. 1b, c, e, and f), consistent with the rapid reduction of $\mathrm{Tc}(\mathrm{VII})$ in all four suspensions. The decrease in the total $\mathrm{Fe}(\mathrm{II})$ was $40-50 \mu \mathrm{mol} \mathrm{L}{ }^{-1}$ for $10 \mu \mathrm{mol} \mathrm{L}^{-1} \mathrm{Tc}(\mathrm{VII})$, and $80-90 \mu \mathrm{mol} \mathrm{L}^{-1}$ for $20 \mu \mathrm{mol} \mathrm{L}{ }^{-1} \mathrm{Tc}(\mathrm{VII})$. The decrease in $\mathrm{Fe}(\mathrm{II})_{\text {TOT }}$ was greater than the stoichiometric demand $[\mathrm{Fe}(\mathrm{II}): \mathrm{Tc}(\mathrm{VII})=3: 1]$ for reduction of $\mathrm{Tc}(\mathrm{VII})$ to $\mathrm{Tc}(\mathrm{IV})$, similar to observations made for reaction of $\mathrm{Tc}(\mathrm{VII})$ with $\mathrm{Fe}(\mathrm{II})_{\mathrm{aq}}$ (Zachara et al., 2007). Heterogeneous Tc(VII) reduction was coincident with, or immediately followed by, a $\mathrm{Fe}(\mathrm{II})_{\mathrm{aq}}$ readsorption step that replenished sorbed $\mathrm{Fe}(\mathrm{II})$ (e.g., Fig. 1b and e).
The heterogeneous reduction of $\mathrm{Tc}(\mathrm{VII})$ in hematite suspensions showed $\mathrm{pH}$ dependency below $\mathrm{pH} 6.5$ (Fig. 2). Very little $\mathrm{Tc}(\mathrm{VII})$ was reduced at $\mathrm{pH} 4$ (e.g., $1.7 \mu \mathrm{mol}$ $\mathrm{L}^{-1}$ ), while slow kinetics were observed at $\mathrm{pH} 4.5$. Experiments performed between $\mathrm{pH}$ 5.6-6.5 displayed rapid reduction kinetics. To a first approximation, the reduction rates paralleled the adsorption density of $\mathrm{Fe}(\mathrm{II})$, Table 1, as $\mathrm{Fe}$ (II) adsorbs on hematite between $\mathrm{pH} 5$ and 6, depending on sorbate and sorbent concentrations (Jeon et al., 2001; Liu et al., 2007).

\subsubsection{Mössbauer spectroscopy of product $\mathrm{Fe}$ (III)}

Mössbauer spectra were obtained for ${ }^{57} \mathrm{Fe}(\mathrm{II})$ adsorbed on ${ }^{56} \mathrm{Fe}$-goethite at $\mathrm{pH} 7$ to identify the nature of reactant $\mathrm{Fe}(\mathrm{II})$, and the $\mathrm{Fe}(\mathrm{III})$ oxidation product resulting from 


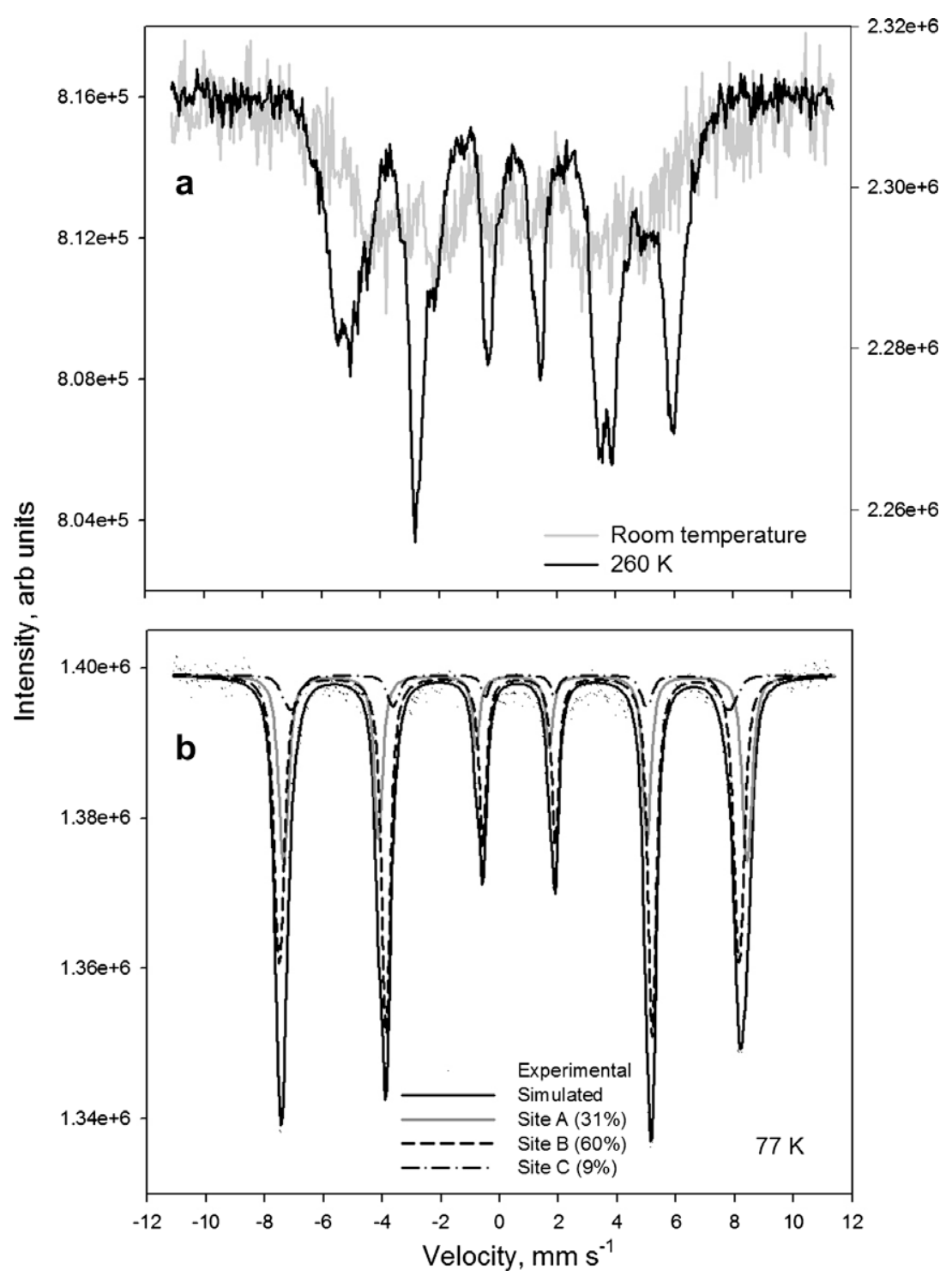

Fig. 3. ${ }^{57} \mathrm{Fe}$ Transmission Mössbauer spectra of ${ }^{56} \mathrm{Fe}$-goethite $\left(1.5 \mathrm{~g} \mathrm{~L}^{-1}\right)$ that had been reacted with ${ }^{57} \mathrm{Fe}^{2+}{ }_{\text {aq) }}\left(0.1 \mathrm{mmol} \mathrm{L}^{-1}\right)$ and then $\mathrm{Tc}$ (VII) $\left(10 \mu \mathrm{mol} \mathrm{L}^{-1}\right)$ at $\mathrm{pH} 7.0$ : (a) room temperature and $260 \mathrm{~K}$ spectra and (b) $77 \mathrm{~K}$ spectra with Recoil modeling of site distributions.

heterogeneous reaction with $\mathrm{Tc}(\mathrm{VII})$. In the suspension studied, almost all of the added ${ }^{57} \mathrm{Fe}(\mathrm{II})\left(0.1 \mathrm{mmol} \mathrm{L}^{-1}\right)$ was sorbed to ${ }^{56} \mathrm{Fe}$-goethite after 2-day equilibration, and only $\sim 3 \times 10^{-3} \mathrm{mmol} \mathrm{L}^{-1}$ of ${ }^{57} \mathrm{Fe}$ (II) remained in the aqueous phase. Pertechnetate that was spiked to this suspension was completely reduced, and no aqueous Fe(II) was detected by the end of the experiment.

The ${ }^{57} \mathrm{Fe}-\mathrm{Mössbauer}$ spectrum of the samples before and after reaction with $\mathrm{Tc}(\mathrm{VII})$ were virtually identical at all measurement temperatures, and only the post-reaction sample is shown (Fig. 3). There was no Fe(II) doublet signal in either sample, or sign of a paramagnetic doublet characteristic of ferrihydrite at temperatures above $77 \mathrm{~K}$ (Murad and Cashion, 2004). The samples displayed a weak, incipient, collapsed sextet at RT (Fig. 3a); a jagged, irregular, but more resolved asymmetric sextet features at $260 \mathrm{~K}$ (Fig. 3b) that was fully resolved at $77 \mathrm{~K}$. The Mössbauer spectrum did not significantly change in either resolution or peak refinement with further temperature reductions below $77 \mathrm{~K}$ (data not shown). The $77-\mathrm{K}$ spectrum could be fit by three components (sites A, B and C): [isomer shift $(\delta)$ $0.48,0.49$ and $0.55 \mathrm{~mm} \mathrm{~s}^{-1}$, quadrupole shift parameter (ع) $0.04,-0.17$, and $-0.19 \mathrm{~mm} \mathrm{~s}^{-1}$, and hyperfine field $\left(B_{\mathrm{hf}}\right)$ 48.9. 48.5 and 45.9 Tesla (T), for sites A, B, and C, respectively]. The derived parameters of all the three sextets are similar to goethite. The noted differences in Mössbauer parameters between the three sextets are due to slight variation in their symmetries. The distribution of the three components changed slightly with $\mathrm{Tc}(\mathrm{VII})$ reaction, but these changes were within the uncertainty of measurement and the applied model. Our $77 \mathrm{~K}$ spectra for both $\mathrm{Fe}(\mathrm{II})$-sorbed and $\mathrm{Tc}(\mathrm{VII})$-reacted goethite were similar to those reported for this same temperature by Silvester et al. (2005) for sorbed ${ }^{57} \mathrm{Fe}(\mathrm{II})$ on natural goethite. 

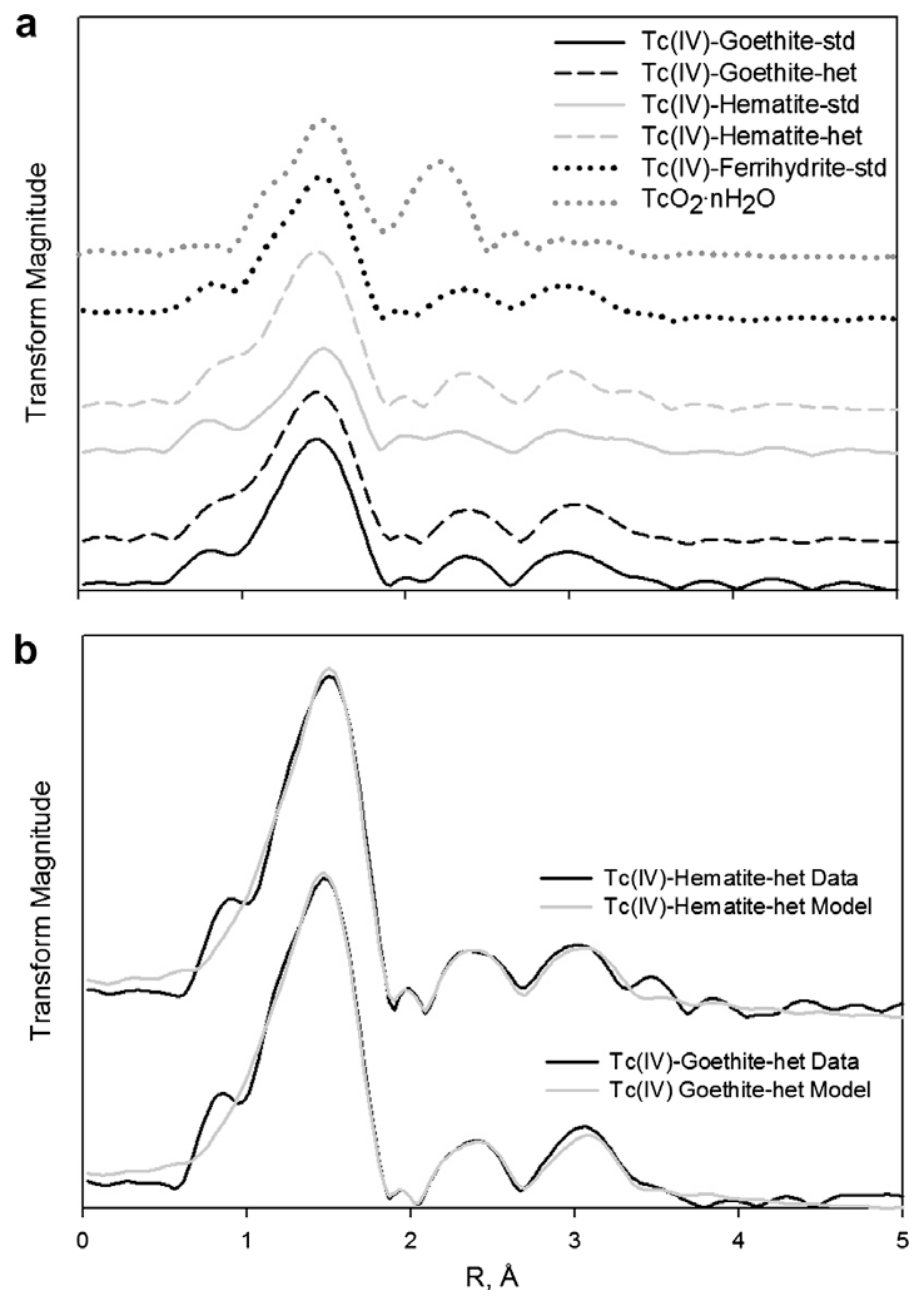

Fig. 4. (a) Tc-EXAFS spectra (Fourier-transform radial distribution function) for $\mathrm{TcO}_{2} \cdot n \mathrm{H}_{2} \mathrm{O}$, Tc(IV) coprecipitated with ferrihydrite, heterogeneously precipitated $\mathrm{Tc}(\mathrm{IV})\left(20 \mu \mathrm{mol} \mathrm{L}^{-1}\right)$ by sorbed $\mathrm{Fe}(\mathrm{II})\left(0.2 \mathrm{mmol} \mathrm{L}^{-1}\right)$ at $\mathrm{pH} 7$ on both hematite $\left(9 \mathrm{~g} \mathrm{~L}^{-1}\right)$ and goethite $\left(1.5 \mathrm{~g} \mathrm{~L}^{-1}\right)$; and $\mathrm{Tc}(\mathrm{IV})$-goethite and -hematite standards. (b) A comparison of experimental and modeled Tc-EXAFS spectra for heterogeneously precipitated $\mathrm{Tc}(\mathrm{IV})$ on goethite and hematite. The model assumed a ferrihydrite-like surface phase as parameterized in Table 2.

\subsubsection{EXAFS spectroscopy of product Tc(IV)}

XANES analyses showed that Tc associated with goethite and hematite after heterogeneous reaction was entirely in the Tc(IV) valence state [energy shift for the Tc(VII)-reduced samples relative to $\mathrm{TcO}_{4}{ }^{-}$was consistent with $\mathrm{Tc}(\mathrm{IV})$ species ( -5.3 to $-5.6 \mathrm{eV}$, Lukens et al., 2002), data not shown]. Radial transforms of the Tc-EXAFS data for Tc(IV) on both goethite and hematite were almost identical (Fig. 4a), with the exception of small outer shell peaks at 3.4 and $3.8 \AA$ for Tc-hematite. These spectra, in turn, were very similar to the Tc(IV)-ferrihydrite standard, which was the originally hypothesized product of $\mathrm{Tc}(\mathrm{VII})$ redox reaction with sorbed Fe(II) (Charlet et al., 1998). The radial transforms for these three, similar samples contrast markedly with that for abiotically precipitated $\mathrm{TcO}_{2} \cdot n \mathrm{H}_{2} \mathrm{O}$, showing the presence of far less Tc-Tc bonding in the second shell (e.g., at $2.3 \AA$ A, Fig. 4a).

A closer inspection of the sample and reference EXAFS spectra revealed uncertainty in the nature of the $\mathrm{Fe}$ (III) sur- face phase and inability to precisely resolve the Fe(III)Tc(IV) structural environment. The reference spectra for the Tc(IV)-ferrihydrite coprecipitate was virtually identical to that for adsorbed Tc(IV) on goethite, and these, in turn were very similar to the heterogeneous Tc(IV)-goethite sample (Fig. 4a). It is possible that Fe(III) dissolved from goethite at low $\mathrm{pH}$ during reference sample synthesis, and that this $\mathrm{Fe}(\mathrm{III})_{\mathrm{aq}}$ hydrolyzed and coprecipitated with $\mathrm{Tc}(\mathrm{IV})$ to yield ferrihydrite upon neutralization. The heterogeneous Tc(IV)-hematite sample was intermediate in character between the hematite and ferrihydrite Tc(IV) standards (Fig. 4a), but all three were quite similar overall. Minimal $\mathrm{Fe}(\mathrm{III})$ dissolution was expected at low $\mathrm{pH}$ with hematite.

The data for heterogeneous $\mathrm{Tc}(\mathrm{IV})$ precipitates on both goethite and hematite were modeled with an edge sharing octahedral model that was previously successfully applied to the Tc(IV)-ferrihydrite standard as described by Zachara et al. (2007). This model was justified because the structural state of $\mathrm{Fe}$ (III) in the heterogeneous precipitates was not 
well constrained by the EXAFS measurements, and the Tc(IV)-ferrihydrite standard was most representative of heterogeneous $\mathrm{Tc}(\mathrm{IV})$ in both systems (Fig. 4a). It consists of a variable length chain of Tc-O octahedra bonded in an edge sharing fashion to an $\mathrm{Fe}-\mathrm{O}$ octahedron located on the surface of the host Fe(III) oxide substrate. In this model the first two shells of neighbors are independent of the structure of the substrate. The details of the substrate is expected to only affect the bonds past about $3 \AA(2.7 \AA$ in the radial transforms where the peaks are shifted to lower $\mathrm{R}$ by the EXAFS phase shifts). The primary objectives of this modeling were to provide insights on the average number of $\mathrm{Tc}(\mathrm{IV})-\mathrm{Tc}(\mathrm{IV})$ bonds and the amount of $\mathrm{Fe}(\mathrm{III})$ in the second coordination sphere of the redox precipitates (both on $\mathrm{Fe}(\mathrm{III})$ oxides and the phyllosilicate mixtures). We note and will later discuss that this host phase is different from that implied by the ${ }^{57} \mathrm{Fe}$ Mössbauer measurements on goethite (Fig. 3).

If the attached $\mathrm{Tc}-\mathrm{O}$ chains consist of a single octahedron (monomers) there would only be Tc-Fe neighbors in the second shell. Initial calculations indicated that the transform data for heterogeneous Tc(IV) precipitates on both goethite and hematite (Fig. 4a) was best fit with a combination of $\mathrm{Tc}(\mathrm{IV})$ and $\mathrm{Fe}(\mathrm{III})$ in the second shell indicating on average the length of the Tc chains is greater than one. For the third peak in the transform (near $3 \AA$ ) the dominant contributions come from the axial oxygens of the neighboring octahedra, and more distant Fe bonds of the substrate. For ferrihydrite, the neighboring $\mathrm{Fe}$ sites are only partially filled and we would expect the Tc directly bonded to the surface to have three of these more distant bonds. For more ordered materials such as hematite, the number of these bonds could be as large as six. This number is not well constrained by the EXAFS fitting, and based on the similarity of the transforms to the ferrihydrite standard, it was fixed at three in the fitting. Based on previous fits and to minimize the fitting parameters, second-shell bond distances were also fixed at $\mathrm{Tc}-\mathrm{Fe}=2.59 \AA$ and $\mathrm{Tc}-$ $\mathrm{Tc}=2.57 \AA$.

Technetium(IV) octahedra have a tendency to polymerize in chains (Lukens et al., 2002), and this was allowed in the model through the number of Tc-Tc bonds $(\mathrm{Tc}-\mathrm{N})$. It

Table 2

EXAFS fit parameters for heterogeneous $\mathrm{Tc}(\mathrm{IV})$ on goethite and hematite

\begin{tabular}{llll}
\hline Shell & $N$ & $R(\AA)$ & $\sigma^{2}\left(\AA^{2}\right)$ \\
\hline Goethite & & & \\
1st O & $5.4(0.4)$ & $2.00(0.01)$ & $0.0057(0.001)$ \\
Fe short & $0.6(0.3)$ & $2.59_{*}$ & $0.0042(0.002)$ \\
Tc & $0.7(0.3)$ & $2.57 *$ & $0.0058(0.002)$ \\
2nd O & $2.6(0.6)$ & $3.04(0.04)$ & $0.0026(0.003)$ \\
Fe long & $1.8(0.5)$ & $3.50(0.03)$ & $0.0077(0.003)$ \\
Hematite & & & \\
1st O & $5.5(0.4)$ & $2.00(0.01)$ & $0.0039(0.001)$ \\
Fe short & $0.5(0.3)$ & $2.59_{*}$ & $0.0020(0.002)$ \\
Tc & $0.9(0.3)$ & $2.57 *$ & $0.0072(0.002)$ \\
2nd O & $2.8(0.6)$ & $3.02(0.04)$ & $0.0018(0.002)$ \\
Fe long & $1.6(0.5)$ & $3.47(0.03)$ & $0.0030(0.002)$ \\
\hline
\end{tabular}

Parameters noted by $*$ were fixed in the data fitting. was assumed that the additional Tc-O octahedra were part of a chain, and therefore not directly bonded to the Fe(III) oxide substrate. As the average chain length of the Tc(IV) octahedra increased, Tc- $\mathrm{N}$ increased, the longer Fe coordination decreased, and axial $\mathrm{O}$ coordination increased. Therefore all of the coordination numbers in Table 2 were either fixed or determined by the $\mathrm{Tc}-\mathrm{N}$ value with the exception of the first shell $\mathrm{O}$ coordination. The resulting model well described the Tc(IV) EXAFS data for both goethite and hematite (Fig. 4b), and the Tc(IV)-ferrihydrite (Zachara et al., 2007) with similar parameters (Table 2). The results gave an average chain length for Tc(IV) octahedra between monomers and dimers, although there was large uncertainty. Model fits with $100 \%$ monomer $(N=0)$ or dimer $(N=1)$ had similar total quality, but some of the parameters became unphysical indicating an intermediate value was best. The EXAFS results provide an average Tc environment. By itself EXAFS cannot distinguish between a surface with roughly similar amounts of monomers and dimers attached, and a surface with attached monomers and a few isolated long chains of $\mathrm{TcO}_{2} \cdot n \mathrm{H}_{2} \mathrm{O}$.

\subsection{Reduction of $\mathrm{Tc}(\mathrm{VII})$ by $\mathrm{Fe}(\mathrm{II})$ associated with phyllosilicates}

\subsubsection{Nature of the sorbent}

The FRC-dcb sediment contained coarse silt-sized muscovite and quartz $(>10 \mu \mathrm{m})$, and clay-sized illites and vermiculite $(<0.2 \mu \mathrm{m})$ (Kukkadapu et al., 2006). Electron microprobe measurements of the phyllosilicates demonstrated significant $\mathrm{Fe}$ substitution in both size fractions (Kukkadapu et al., 2006). By analogy to results with specimen Fe-containing phyllosilicates extracted with DCB (Stucki et al., 1984; Bain and Smith, 1994; Hofstetter et al., 2003, 2006), we assumed that a dominant fraction (e.g., $>95 \%$ ) of the $\mathrm{Fe}(\mathrm{II})$ remained in structural state after extraction, while the remainder $(<5 \%)$ was edge-complexed to hydroxylated sites. We made no attempt to extract edgecomplexed Fe(II) from the FRC-dcb sediments to evaluate either its concentration or potential contribution to $\mathrm{Tc}$ (VII) heterogeneous reduction because of concerns of extraction specificity. Previous wet chemical studies of this reduced material have shown complex dissolution behavior in weak acid (Kukkadapu et al., 2006) that may result from the presence of Fe-containing phyllosilicates in both size fractions. The small Fe-containing phyllosilicates were readily reduced by DCB and dissolved rapidly and completely in weak acid. Distinguishing surface-complexed Fe(II) from submicron-sized phyllosilicates was not deemed feasible.

${ }^{57} \mathrm{Fe}-\mathrm{Möss} b a u e r$ measurements of the FRC-dcb (Fig. 5a) indicated that most of the sample Fe existed within phyllosilicates with a $\mathrm{Fe}(\mathrm{II}) / \mathrm{Fe}_{\mathrm{TO}}$ ratio of 0.46 . A 2-h weak acid extraction of the FRC-dcb dissolved over $22 \%$ of the Mössbauer-visible $\mathrm{Fe}(\mathrm{II})$ (Fig. 5b). This removal changed the peak areas of the $\mathrm{Fe}(\mathrm{II})$ and $\mathrm{Fe}(\mathrm{III})$ doublets, but not their peak positions [e.g., the quadrupole splitting of $\mathrm{Fe}(\mathrm{II})]$.

\subsubsection{Heterogeneous reduction behavior}

It was hypothesized that $\mathrm{Fe}(\mathrm{II})_{\mathrm{aq}}$ added to suspensions of FRC-dcb would adsorb primarily by ion exchange and 


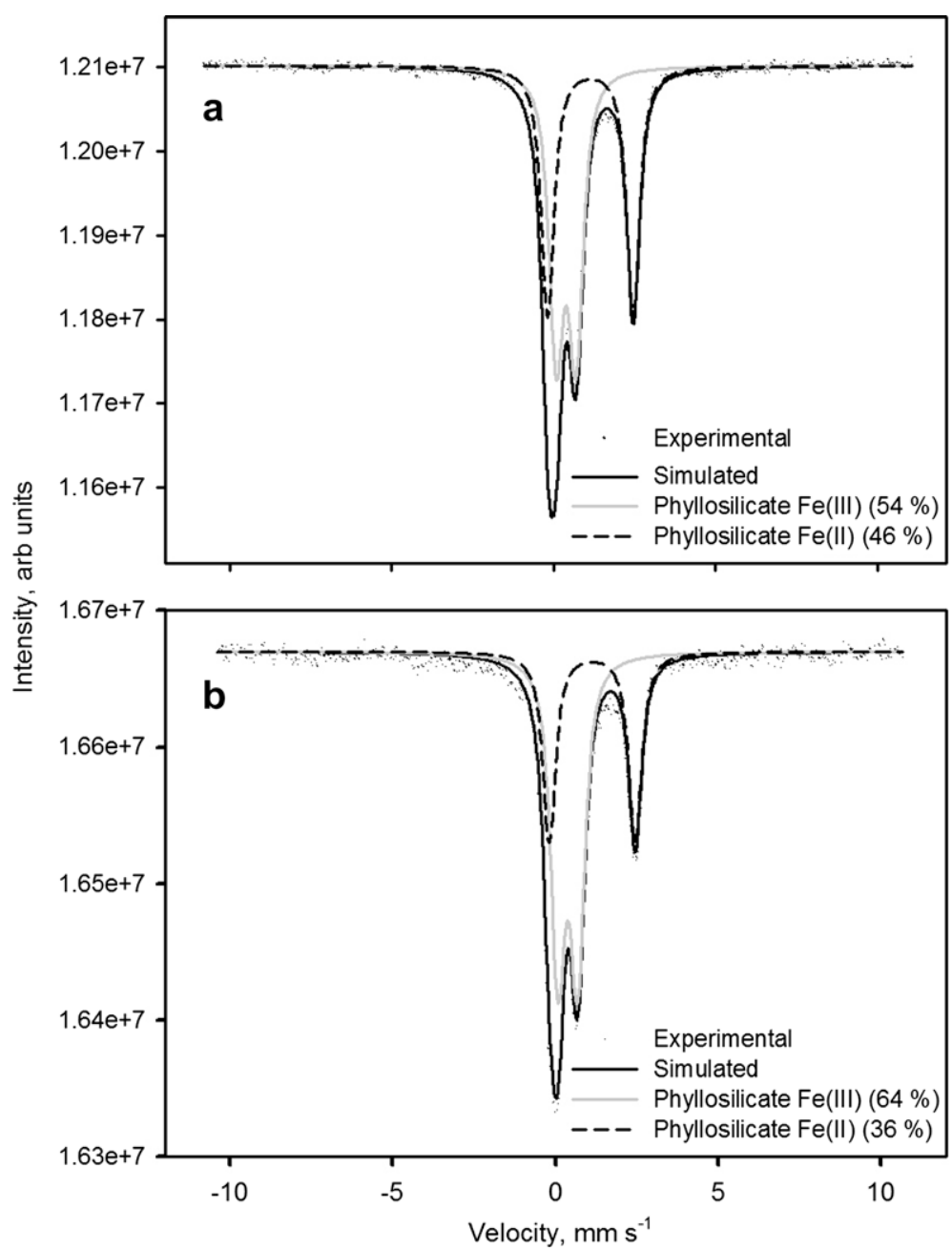

Fig. 5. Room temperature ${ }^{57} \mathrm{Fe}$ transmission Mössbauer spectra for the DCB-treated FRC phyllosilicate mineral isolate: (a) before and (b) after weak acid $\left(0.5 \mathrm{~L}^{-1} \mathrm{HCl}\right)$ extraction. Recoil modeling was applied to estimate the distribution of phyllosilicate $\mathrm{Fe}(\mathrm{II})$ and $\mathrm{Fe}(\mathrm{III})$ in the two samples.

by some edge complexation, and that the heterogeneous reduction rate would increase proportionally. This hypothesis, however, was refuted by experiment where heterogeneous $\mathrm{Tc}(\mathrm{VII})$ reduction was found to be independent of added $\mathrm{Fe}$ (II) concentration (Fig. 6a), and slower than observed for either hematite or goethite. The FRC-dcb adsorbed all the dissolved $\mathrm{Fe}(\mathrm{II})_{\mathrm{aq}}$ upon addition to the reactor (Fig. 6b). This adsorption approximately doubled the total $\mathrm{Fe}(\mathrm{II})$ concentration associated with the composite mineral phase (Fig. 6c). The total $\mathrm{Fe}$ (II) shown for days -2 to 6 is the sum of intrinsic (structural/edge-complexed) and ion-exchangeable $\mathrm{Fe}(\mathrm{II})$. For both experiments, the total amount of $\mathrm{Fe}(\mathrm{II})$ was in vast excess of the stoichiometric demand for $\mathrm{Tc}(\mathrm{VII})$ reduction (Fig. 6c), and no statistical differences in total $\mathrm{Fe}$ (II) could be determined before and after reduction.

The FRC-dcb functioned as a heterogeneous reductant for $\mathrm{Tc}(\mathrm{VII})$ in the absence of added $\mathrm{Fe}(\mathrm{II})$, with apparent rates that were independent of both $\mathrm{pH}$ and solids concentration (Fig. 7a), and that were nearly identical to those in Fig. 6. Therefore, the added Fe(II) adsorbed by ion exchange and possibly edge complexation had no heterogeneous reduction capability for $\mathrm{Tc}(\mathrm{VII})$. Rather, the presence of appreciable weak acid extractable intrinsic $\mathrm{Fe}(\mathrm{II})$ in the FRC-dcb (Fig. 7b) lead us to speculate that structural Fe(II) associated with fine, clay-sized phyllosilicates, and an unquantified amount of edge-complexed Fe(II) were the responsible reductants. These hypotheses were further tested and affirmed (Fig. 8), where Tc(VII) reactivity was assessed in suspensions of HCl-treated FRC-dcb that were spiked with $\mathrm{Fe}(\mathrm{II})_{\text {aq }}$. These suspensions demonstrated high-Fe(II) adsorption by ion exchange and some potential edge complexation (Fig. 8b), and no apparent reduction of $\mathrm{Tc}(\mathrm{VII})$ (Fig. 8a) or Fe(II) oxidation (Fig. 8c). The lack of any observed effect of increasing added $\mathrm{Fe}(\mathrm{II})_{\mathrm{aq}}$ concentration on $\mathrm{Tc}$ (VII) reduction by the FRC-dcb-HCl (Fig. 8) suggested that $\mathrm{Fe}$ (II) edge complexes were not significant reductants (e.g., Figs. 6 and 7). The large residual Mössbauer Fe(II) signal remaining after weak acid extraction (Fig. 5b) was, therefore, associated with phyllosilicate phases incapable of heterogeneous $\mathrm{Tc}(\mathrm{VII})$ reduction, such as silt-sized, Fe(II)containing micas. 

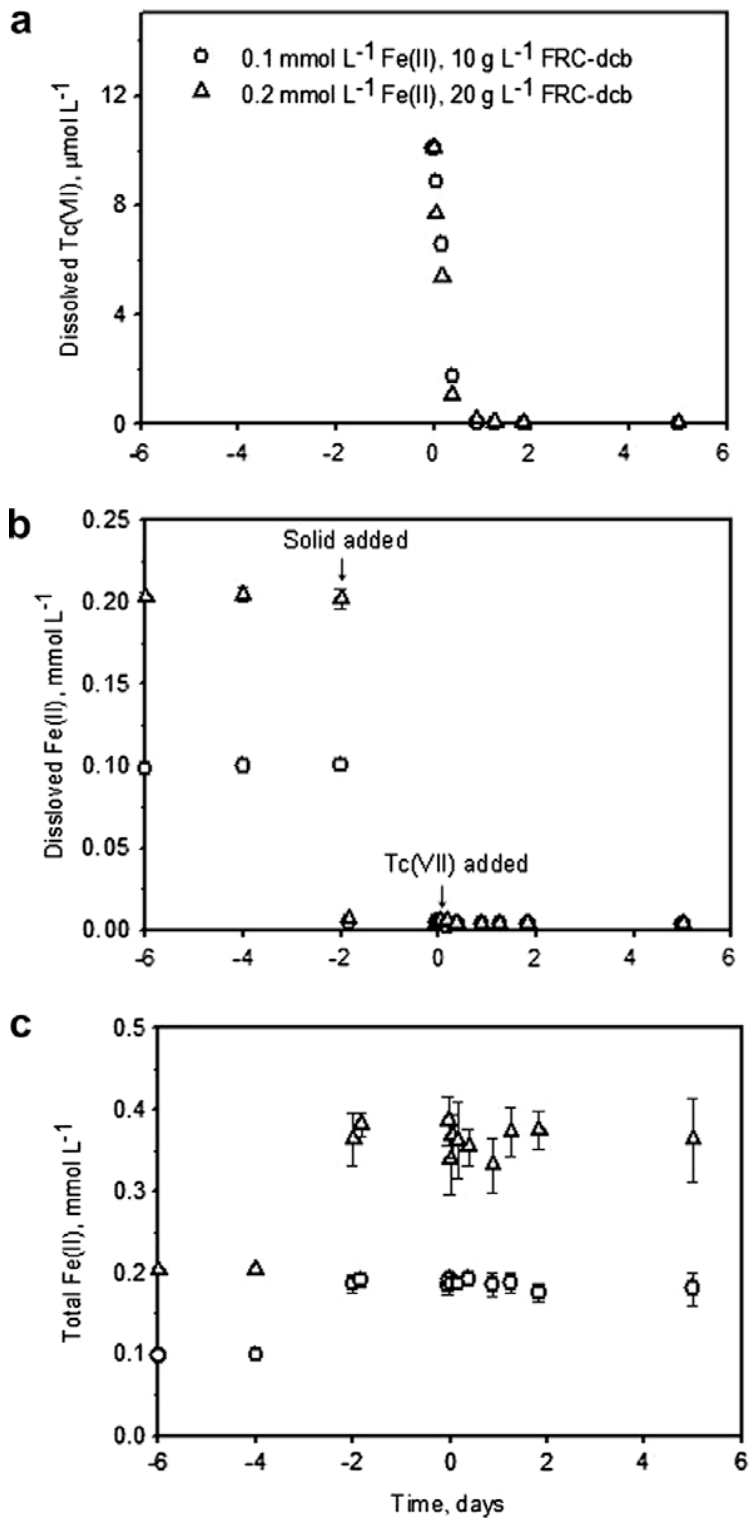

Fig. 6. Time-dependent behavior of two $\mathrm{Fe}^{2+}{ }_{\text {(aq) }}$ solutions $(0.2$ and $0.1 \mathrm{mmol} \mathrm{L}^{-1}$ ) at $\mathrm{pH} 7$ that were spiked with DCB-treated FRC phyllosilicate isolate $\left(20\right.$ and $10 \mathrm{~g} \mathrm{~L}^{-1}$ at day -2$)$ and $\mathrm{Tc}(\mathrm{VII})$ (10 $\mu \mathrm{mol} \mathrm{L}^{-1}$ at day 0): (a) $\mathrm{Tc}(\mathrm{VII})$, (b) dissolved Fe(II), and (c) total $\mathrm{Fe}(\mathrm{II})$. Data represent means $( \pm \mathrm{SD})$ of triplicate samples.

\subsubsection{EXAFS spectroscopy of product $T c(I V)$}

Radial transforms of the Tc(IV) EXAFS data from FRC-dcb1 and FRC-dcb2 were nearly identical to one another (Fig. 9a) and quite different from heterogeneous $\mathrm{Tc}(\mathrm{IV})$ on goethite and hematite. The two FRC samples showed evidence for more Tc-Tc bonding in the second shell (e.g., $2.3 \AA$ ). The ferrihydrite model described above was changed to a combination of Tc-Fe monomers and Tc-Tc chains as in $\mathrm{TcO}_{2} \cdot n \mathrm{H}_{2} \mathrm{O}$. The contribution from the $\mathrm{Tc}-\mathrm{Fe}$ bond was found to be small, and its parameters were consequently fixed at values from the Fe(III) oxide system. When optimized with the fixed values in Table 3; the model fitted the data well (Fig. 9b) while simultaneously
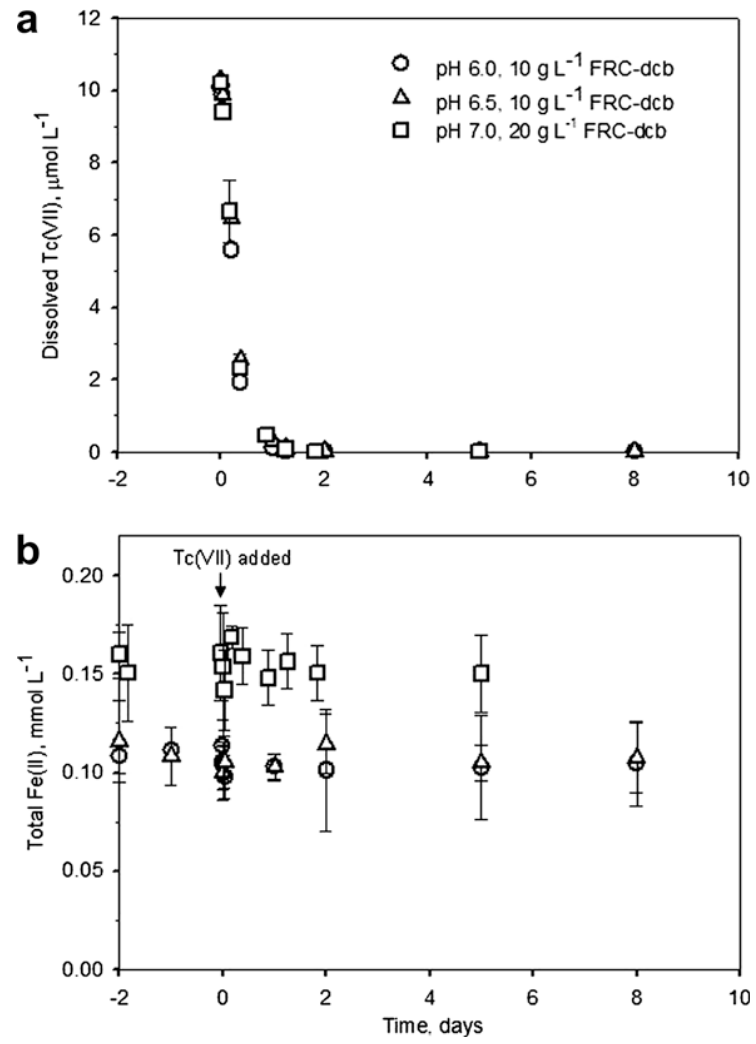

Fig. 7. Influence of $\mathrm{pH}$ on the reduction of $\mathrm{Tc}(\mathrm{VII})\left(10 \mu \mathrm{mol} \mathrm{L}{ }^{-1}\right.$ spiked at day 0) by the DCB-treated FRC phyllosilicate isolate: (a) $\mathrm{Tc}(\mathrm{VII})$ and (b) total $\mathrm{Fe}(\mathrm{II})$. No additional $\mathrm{Fe}^{2+}{ }_{(\mathrm{aq})}$ was added to the suspension beyond that associated with the mineral fraction. Data represent means $( \pm \mathrm{SD})$ of triplicate samples.

refining to parameters for the Tc-Tc chains that were similar to $\mathrm{TcO}_{2} \cdot n \mathrm{H}_{2} \mathrm{O}$. Generally the Tc-Tc chain length in the precipitate was found to be consistently larger than a dimer (e.g., $N>1$ ).

The high quality of our near edge data for samples and standards allowed us to test an alternative model for the FRC samples as a combination of Tc(IV)-ferrihydrite and $\mathrm{TcO}_{2} \cdot n \mathrm{H}_{2} \mathrm{O}$. This additive model yielded $35 \% \mathrm{Tc}(\mathrm{IV})$-ferrihydrite and $65 \% \mathrm{TcO}_{2} \cdot n \mathrm{H}_{2} \mathrm{O}$ for $\mathrm{FRC}-\mathrm{dcb} 1$, and $30 \%$ $\mathrm{Tc}(\mathrm{IV})$-ferrihydrite and $70 \% \mathrm{TcO}_{2} \cdot n \mathrm{H}_{2} \mathrm{O}$ for $\mathrm{FRC}-\mathrm{dcb} 2$. These values were reasonably consistent with the EXAFS fitting in terms of the amount of Tc-Tc and Tc-Fe bonds. The values would be exactly consistent if the Tc(IV)-ferrihydrite contained all $\mathrm{Tc}(\mathrm{IV})$ as dimers.

\subsection{Rate constants and comparative kinetic behavior}

A kinetic analysis was performed on the heterogeneous $\mathrm{Tc}(\mathrm{VII})$ reduction data in Figs. 1, 2, 6, and 7 using the initial data points that showed a linear relationship between $\ln \left(C_{\mathrm{t}} / C_{0}\right)$ vs. time. The reduction kinetics of $\mathrm{Tc}(\mathrm{VII})$ could be described with a first-order rate law, yielding the resulting pseudo-first-order rate constants, $k_{\text {obs }}$, summarized in Table 1.

The rate constants computed for hematite and goethite were similar to one another under comparable conditions, 
a
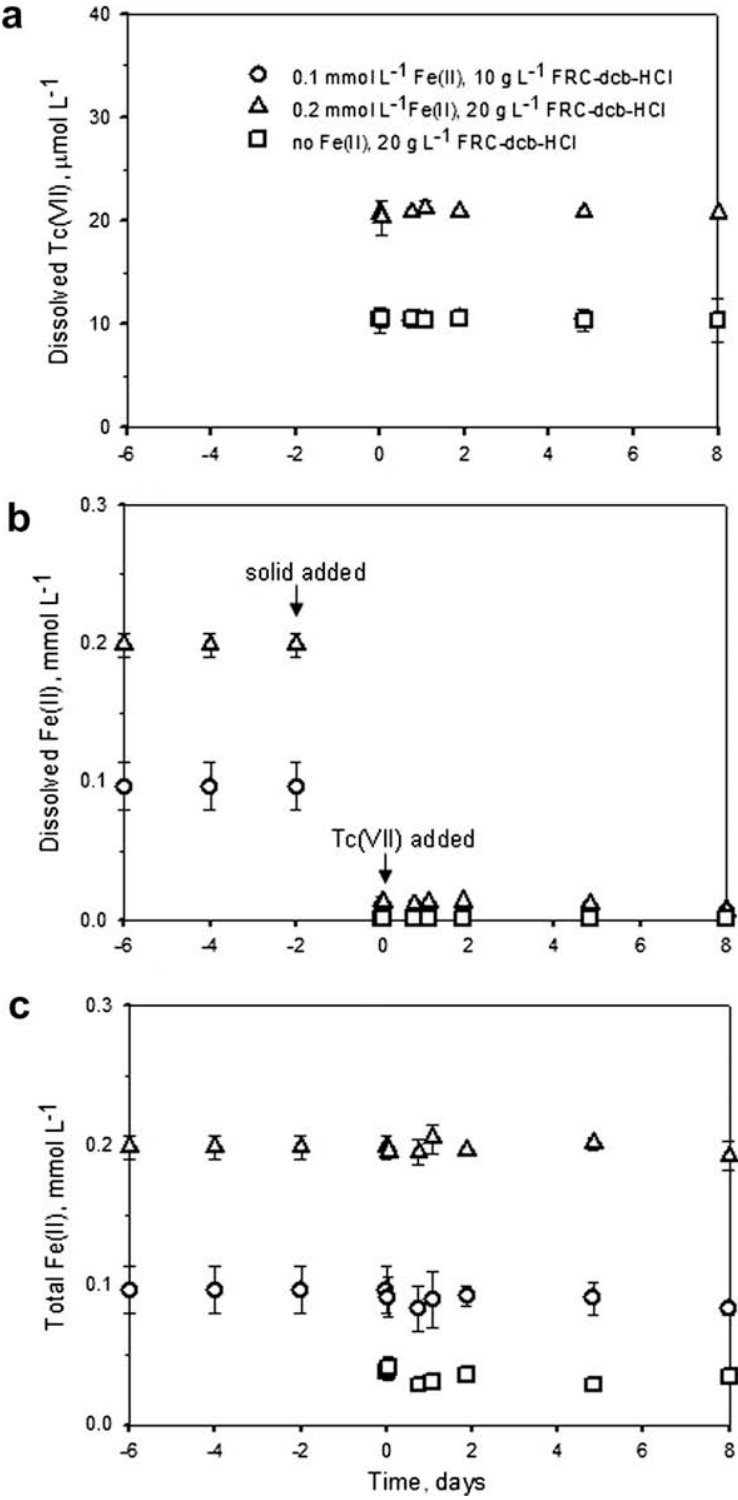

Fig. 8. Influence of $0.5 \mathrm{~mol} \mathrm{~L}^{-1} \mathrm{HCl}$ extraction of the DCBtreated FRC phyllosilicate isolate (spiked at day -2) on the reduction of $\mathrm{Tc}(\mathrm{VII})$ at $\mathrm{pH} 7$ at two added $\mathrm{Fe}^{2+}{ }_{(\text {aq })}$ concentrations: (a) dissolved $\mathrm{Tc}(\mathrm{VII})$, (b) dissolved $\mathrm{Fe}(\mathrm{II})$, and (c) total $\mathrm{Fe}(\mathrm{II})$. Solid and $\mathrm{Tc}(\mathrm{VII})$ concentrations varied as noted. There was no $\mathrm{Tc}(\mathrm{VII})$ reduction. Data represent means $( \pm \mathrm{SD})$ of triplicate samples.

but these differed markedly from the FRC-dcb. Those for the $\mathrm{Fe}(\mathrm{III})$ oxides increased with sorbed $\mathrm{Fe}(\mathrm{II})$ concentration, with $k_{\mathrm{obs}}=15.14 \mathrm{~h}^{-1}$ ( $\left.\mathrm{pH} 6.5\right)$ being the highest value that could be defensibly quantified by regression analysis. The heterogeneous reduction rate was so fast at $\mathrm{pH} 7$ that it could not be established by wet chemical measurement (e.g., $k_{\text {obs }}>16 \mathrm{~h}^{-1}$ ). For those conditions where the rate was quantified (Fig. 10), $k_{\text {obs }}$ demonstrated an exponential dependence on sorbed $\mathrm{Fe}$ (II) concentration indicating that other factors related to $\mathrm{pH}$ such as $\mathrm{Fe}(\mathrm{II})$ surface complex hydrolysis (e.g., $=\mathrm{Fe}^{\mathrm{III}} \mathrm{OFe}^{\mathrm{II}} \mathrm{OH}^{\mathrm{o}}$; Charlet et al., 1998; Silvester et al., 2005) were at play.
In contrast to the $\mathrm{Fe}(\mathrm{III})$ oxides, the heterogeneous reduction rate of $\mathrm{Tc}(\mathrm{VII})$ was univariant on $\mathrm{FRC}-\mathrm{dcb}$. The reduction rate of FRC-dcb was determined by its "intrinsic $\mathrm{Fe}(\mathrm{II})$ concentration", and was not influenced by additional sorbed $\mathrm{Fe}(\mathrm{II})$, or by a one unit change in $\mathrm{pH}$. The reduction rates on hematite and goethite [with 0.16-0.17 $\mathrm{mmol} \mathrm{L}^{-1}$ sorbed $\left.\mathrm{Fe}(\mathrm{II})\right]$ were: (i) close to, but in excess of those observed for sorbed biogenic $\mathrm{Fe}(\mathrm{II})$ in $\mathrm{Fe}(\mathrm{III})$-oxide containing sediment (Fredrickson et al., 2004) by factors of 2-3, (ii) over 100 times that of the FRC-dcb [with $0.09-0.18 \mathrm{mmol} \mathrm{L}^{-1}$ intrinsic $\mathrm{Fe}(\mathrm{II})$ ], and (iii) over $10^{4}$ times the homogeneous reduction rate of $\mathrm{Tc}(\mathrm{VII})$ by $\mathrm{Fe}(\mathrm{II})_{\text {aq }}$ reported by Zachara et al. (2007). The following qualitative affinity series for heterogeneous $\mathrm{Tc}(\mathrm{VII})$ reduction by $\mathrm{Fe}(\mathrm{II})$ was suggested by the experimental results: aqueous $\mathrm{Fe}(\mathrm{II}) \sim$ adsorbed $\mathrm{Fe}(\mathrm{II})$ in phyllosilicates [ion-exchangeable and some edge-complexed $\mathrm{Fe}(\mathrm{II})] \ll$ structural $\mathrm{Fe}(\mathrm{II})$ in phyllosilicates $\ll \mathrm{Fe}(\mathrm{II})$ adsorbed on $\mathrm{Fe}(\mathrm{III})$ oxides.

\section{DISCUSSION}

\subsection{Tc-redox thermodynamics}

As described recently by Zachara et al. (2007), the redox behavior of the $\mathrm{Tc}(\mathrm{IV}) / \mathrm{Tc}(\mathrm{VII})$ couple bears similarity to that of $\mathrm{Cr}(\mathrm{III}) / \mathrm{Cr}(\mathrm{VI})$, in terms of an overall three-electron transfer reaction that links a soluble oxidized anion, to a stable insoluble oxyhydroxide precipitate of lower valence. The $\mathrm{Tc}(\mathrm{IV}) / \mathrm{Tc}(\mathrm{VII})$ couple is more reducing than the $\mathrm{Cr}(\mathrm{III}) / \mathrm{Cr}(\mathrm{VI})$ couple (Rard et al., 1999):

$$
\begin{array}{r}
\mathrm{TcO}_{4}{ }^{-}+4 \mathrm{H}^{+}+3 \mathrm{e}^{-}=\mathrm{TcO}_{2} \cdot n \mathrm{H}_{2} \mathrm{O}_{(\mathrm{s})}+(2-n) \mathrm{H}_{2} \mathrm{O} \\
\mathrm{E}^{\mathrm{o}}=0.748 \mathrm{~V} \quad \log K=37.8
\end{array}
$$

At circumneutral $\mathrm{pH}$, the homogeneous reduction reaction of Tc(VII) with ferrous iron is thermodynamically favorable over a fairly wide range of $\mathrm{Fe}^{2+}{ }_{(\mathrm{aq})}$ and environmentally relevant $\mathrm{Tc}(\mathrm{VII})$ concentrations (e.g., $10^{-4}$ $10^{-9} \mathrm{~mol} \mathrm{~L}^{-1}$ ):

$$
\begin{gathered}
\mathrm{TcO}_{4}{ }^{-}+3 \mathrm{Fe}^{2+}+(7-n) \mathrm{H}_{2} \mathrm{O}=\mathrm{TcO}_{2} \cdot n \mathrm{H}_{2} \mathrm{O}_{(\mathrm{s})} \\
+3 \mathrm{Fe}(\mathrm{OH})_{3(\mathrm{~s})}+5 \mathrm{H}^{+} \quad \log K=-13.5
\end{gathered}
$$

Unlike the comparable reaction for $\mathrm{Cr}(\mathrm{VI})$, reaction (2) proceeds very slowly in the circumneutral $\mathrm{pH}$ range $(\mathrm{Za}-$ chara et al., 2007). The "real" reaction (2) yields a complex $\mathrm{Tc}(\mathrm{IV}): \mathrm{Fe}(\mathrm{II} / \mathrm{III})$ solid phase redox product that is intermediate in character between ferrihydrite and magnetite ( $\mathrm{Za}$ chara et al., 2007). The redox product significantly accelerates further $\mathrm{Tc}(\mathrm{VII})$ reduction through $\mathrm{Fe}(\mathrm{II})$ sorption and heterogeneous reaction.

The slow rate of homogeneous reduction under favorable conditions has been speculated to result from the slow kinetic reactivity of the hydrated $\mathrm{Fe}^{2+}{ }_{\text {(aq) }}$ ion and the existence of intermediate valence forms $[\mathrm{Tc}(\mathrm{VI}), \mathrm{Tc}(\mathrm{V})]$ with significantly lower redox potentials than the final, stable Tc(IV) valence state (Cui and Eriksen, 1996a; Rard et al., 1999; Zachara et al., 2007). A schematic of the three electron transfer process is shown in Fig. 11, based on Cui and Eriksen (1996a), Rard et al. (1999). In this 

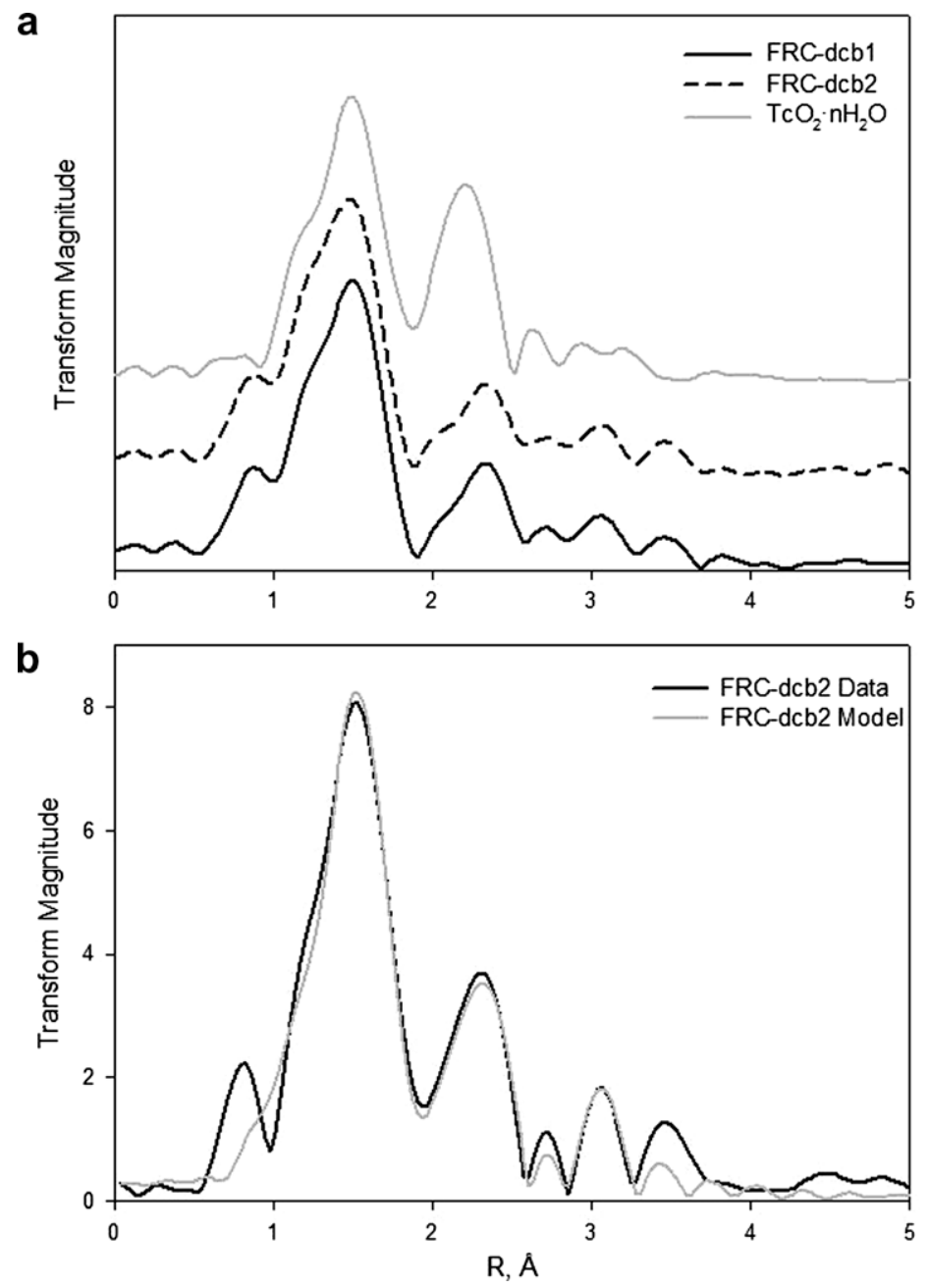

Fig. 9. (a) Tc-EXAFS spectra (Fourier-transform radial distribution function) for $\mathrm{TcO}_{2} \cdot n \mathrm{H}_{2} \mathrm{O}$, and heterogeneously precipitated Tc(IV) $\left(10 \mu \mathrm{mol} \mathrm{L}^{-1}\right)$ on the DCB-treated FRC phyllosilicate isolates at pH $6.0\left(\mathrm{FRC}-\mathrm{dcb} 1,10 \mathrm{~g} \mathrm{~L}^{-1}\right)$ and $\mathrm{pH} 6.5(\mathrm{FRC}-\mathrm{dcb} 2,10 \mathrm{~g} \mathrm{~L}-1)$ in the absence of additional $\mathrm{Fe}(\mathrm{II})_{\mathrm{aq}}$, (b) a comparison of data and EXAFS model calculations as described in the text with model parameters summarized in Table 3.

Table 3

EXAFS fit parameters for heterogeneous Tc(IV) on DCB-treated, FRC phyllosilicate mixtures

\begin{tabular}{llll}
\hline Shell & $N$ & $R(\AA)$ & $\sigma^{2}\left(\AA^{2}\right)$ \\
\hline$F R C-d c b 1, p H 6$ & & & \\
1st O & $6_{*}$ & $2.01(0.01)$ & $0.0062(0.001)$ \\
Fe short & $0.17(0.2)$ & $2.58_{*}(0.02)$ & $0.008_{*}(0.002)$ \\
Tc & $1.7(0.3)$ & $2.57_{*}$ & $0.0058(0.002)$ \\
2nd O short & $4 *$ & $3.24(0.04)$ & $0.017(0.003)$ \\
Fe long & 0.4 & $3.49(0.03)$ & $0.0012(0.002)$ \\
FRC-dcb2, pH 6.5 & & \\
1st O & $6 *$ & $2.01(0.01)$ & $0.0062(0.001)$ \\
Fe short & $0.13(0.2)$ & $2.58_{*}(0.02)$ & $0.008_{*}(0.002)$ \\
Tc & $1.7(0.3)$ & $2.57_{*}$ & $0.0072(0.002)$ \\
2nd O short & $4 *$ & $3.19(0.04)$ & $0.0034(0.002)$ \\
Fe long & 0.4 & $3.48(0.03)$ & $0.0030(0.002)$ \\
\hline Parameter & &
\end{tabular}

Parameters noted by $*$ were fixed in the data fitting.

reaction series, pertechnetate engages in a one electron transfer reaction with low half-cell potential to yield a structurally comparable, but energetic tetrahedral oxyanion, $\mathrm{TcO}_{4}{ }^{2-}$ :

$\mathrm{TcO}_{4}^{-}+\mathrm{e}^{-}=\mathrm{TcO}_{4}^{2-} \quad \mathrm{E}^{\mathrm{o}}=-0.64 \mathrm{~V}$

Technetium(VI), in turn, rapidly disproportionates to $\mathrm{Tc}(\mathrm{V})$ and $\mathrm{Tc}(\mathrm{VII})$, and $\mathrm{Tc}(\mathrm{V})$ very rapidly disproportionates to $\mathrm{Tc}(\mathrm{IV})$ and $\mathrm{Tc}(\mathrm{VI})$. Continued cycles of one electron transfer combined with disproportionation lead to reaction completion.

The reaction series in Fig. 11 is driven by an electron donor with sufficiently low redox potential to move reaction (3) to the right, as facilitated by rapid rates of disproportionation that maintain low concentrations of the intermediate valence states. The rate of reaction (3) is likely to be rate-controlling in the transformation of $\mathrm{Tc}(\mathrm{VII})$ to $\mathrm{Tc}(\mathrm{IV})$. At circumneutral $\mathrm{pH}$ and the $[\mathrm{Fe}(\mathrm{II})]_{\text {TOT }}$ and $[\mathrm{Tc}(\mathrm{VII})]_{\text {TOT }}$ concentrations used in our experiments, various iron couples exhibit sufficient free energy to generate $\mathrm{TcO}_{4}{ }^{2-}$. These couples include the following listed in their order of redox potential (lowest to highest) under our specific experimental 


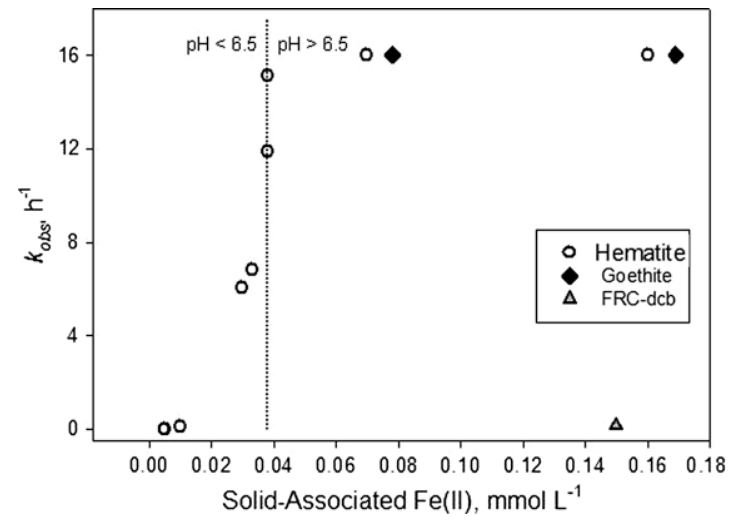

Fig. 10. A comparison of first order apparent rate constants for $\mathrm{Tc}$ (VII) heterogeneous reduction (from Table 1) as a function of solid-associated $\mathrm{Fe}(\mathrm{II})$. The marked differences in rate between the $\mathrm{Fe}(\mathrm{III})$ oxide and FRC phyllosilicate systems are evident. Heterogeneous reduction rates above $\mathrm{pH} 6.5$ for both hematite and goethite were too rapid to quantify (e.g., $k_{\text {obs }}$ ) from regression analysis.

conditions: $\quad \mathrm{Fe}_{(\mathrm{aq})}^{2+} / \mathrm{Fe}_{2} \mathrm{O}_{3(\mathrm{~s})}<\mathrm{Fe}_{(\mathrm{aq})}^{2+} / \mathrm{FeOOH}_{(\mathrm{s})}<=\mathrm{Fe}^{\mathrm{III}}$ $\mathrm{OFe}^{\mathrm{II}} \mathrm{OH}^{\mathrm{o}} /=\mathrm{Fe}^{\mathrm{III}} \mathrm{OH}, \quad \mathrm{FeOOH}_{(\mathrm{s})}$ or $\mathrm{Fe}_{2} \mathrm{O}_{3(\mathrm{~s})}$ [where $=\mathrm{Fe}^{\mathrm{III}} \mathrm{OH}$ is a surface site and $=\mathrm{Fe}^{\mathrm{III}} \mathrm{OFe}^{\mathrm{II}} \mathrm{OH}^{\mathrm{O}}$ is the hydrolyzed ferrous iron surface complex; (Silvester et al., $2005)]<\mathrm{Fe}_{(\mathrm{aq})}^{2+} / \mathrm{Fe}(\mathrm{OH})_{3(\mathrm{~s})}$ [standard state half-cell potentials taken from: Cornell and Schwertmann (2000) for the $\mathrm{Fe}(\mathrm{III})$ oxides, Rard et al. (1999) for the Tc(VII)/Tc(VI) couple, and (Silvester et al., 2005) for the Fe(II) surface complexes; experimental redox potentials calculated with the Nernst equation].

The rapid reduction rates of $\mathrm{Tc}(\mathrm{VII})$ in our experimental systems with sorbed $\mathrm{Fe}(\mathrm{II})$ on crystalline Fe(III) oxides, and the exponential increase in rate constants with increasing sorbed $\mathrm{Fe}(\mathrm{II})$ and $\mathrm{pH}$ (Fig. 10) implicated the $=\mathrm{Fe}^{\mathrm{III}} \mathrm{OFe}^{\mathrm{II}} \mathrm{OH}^{\mathrm{o}} /=\mathrm{Fe}^{\mathrm{III}} \mathrm{OH}, \mathrm{FeOOH}_{(\mathrm{s})}$ or $\mathrm{Fe}_{2} \mathrm{O}_{3(\mathrm{~s})}$ couples, as rapid kinetic reductants for $\mathrm{Tc}(\mathrm{VII})$. This unique reactant as described by Charlet et al. (1998), Silvester et al. (2005) forms through enhanced or heterogeneous hydrolysis at the oxide-water interface. The reactivity of this surface species for $\mathrm{Tc}(\mathrm{VII})$ is remarkably rapid, as virtually instantaneous reduction occurs at $\mathrm{pH} 6.5$ and above, even in the absence of measurable $\mathrm{Tc}(\mathrm{VII})$ adsorption. The molecular nature of this surface entity is under debate [e.g., Williams and Scherer, 2004], as will be discussed in the next section. Our results suggest that the reaction series in Fig. 11 is kinetically expedited at the solid-water interface of $\mathrm{Fe}$ (III) oxides.

The redox potential of structural $\mathrm{Fe}^{\mathrm{II}} / \mathrm{Fe}^{\mathrm{III}}$ sites in the phyllosilicate octahedral layer, the presumed dominant reductant in our phyllosilicate experiments, have not been formally measured but are believed to be lower than those of aqueous $\mathrm{Fe}(\mathrm{II}) / \mathrm{Fe}(\mathrm{III})$ couples and higher than those of sorbed Fe(II) on Fe(III) oxides (Amonette et al., 2000). The redox chemistry of $\mathrm{Fe}(\mathrm{II})$ in the octahedral layer is complex, and in high Fe-smectites can involve intra-solid migration to form reactive $\mathrm{Fe}(\mathrm{II})$ clusters involving $\mathrm{Fe}^{\mathrm{II}}-\mathrm{O}-\mathrm{Fe}^{\mathrm{II}}$

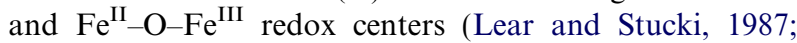
Komadel et al., 1990).

\subsection{Reduction mechanisms and implications of product speciation}

\subsubsection{Fe(III) oxides}

Tc-EXAFS measurements of the product of heterogeneous reduction were virtually identical on both hematite and goethite, and these in-turn, were like the Tc(IV)-ferrihydrite standard (Fig. 4a) and ferrihydrite-like redox products resulting from the homogeneous reaction of $\mathrm{Tc}(\mathrm{VII})$ and $\mathrm{Fe}^{2+}{ }_{\text {(aq) }}$ (Zachara et al., 2007). While the contribution of second shell $\mathrm{Fe}$ to all of the Tc spectra was unmistakable, the precise nature of $\mathrm{Fe}(\mathrm{III})$ in, or associated with, the redox products was indeterminate as shown by the similarity in the Tc(IV)-ferrihydrite, -goethite, and -hematite reference spectra (Fig. 4a). It is possible that $\mathrm{Fe}(\mathrm{III})$ was solubilized at low $\mathrm{pH}$ during $\mathrm{Tc}(\mathrm{IV})$-goethite and Tc(IV)-hematite standard synthesis (Jang et al., 2007) which precipitated as ferrihydrite in association with Tc(IV) at higher $\mathrm{pH}$. These ambiguities and close similarities between the EXAFS spectra of samples and the Tc(IV)-ferrihydrite standard led us to apply the EXAFS model of Zachara et al. (2007) that involved either the substitution within, or direct surface complexation of Tc(IV) octahedral monomers and dimers to a defected, ferrihydrite-like structure. This model yielded excellent fits of the EXAFS spectra (Fig. 4b), with reasonable structural parameters (Table 2). The identity of the heterogeneous Tc(IV) product as a surface complex to ferrihydrite, goethite, or hematite, or as a co-precipitate was indeterminate because of large, outer shell disorder, and minor apparent influence of $\mathrm{Fe}(\mathrm{III})$ structure on Tc-EXAFS results. Any of these end states could result from the direct redox reaction of $\mathrm{Tc}(\mathrm{VII})$ with surface $\mathrm{Fe}(\mathrm{II})$ complexes (e.g., $=\mathrm{Fe}^{\mathrm{III}} \mathrm{OFe}^{\mathrm{II}+}$ or $=\mathrm{Fe}^{\mathrm{III}} \mathrm{OFe}^{\mathrm{II}} \mathrm{OH}^{\mathrm{o}}$; Charlet et al., 1998); or reactive surface $=\mathrm{Fe}(\mathrm{III})-\mathrm{OH}_{2}{ }^{2+}$ sites that serve as conduits for transfer of internal, delocalized electron density.

Recent ${ }^{57} \mathrm{Fe}$ Mössbauer measurements at sub-monolayer concentrations suggest that sorbed $\mathrm{Fe}(\mathrm{II})$ on $\mathrm{Fe}(\mathrm{III})$ oxides is oxidized by the bulk solid, and does not retain the molecular configuration of a classic surface Fe(II) complex (Williams and Scherer, 2004, 2005). Mössbauer mea-

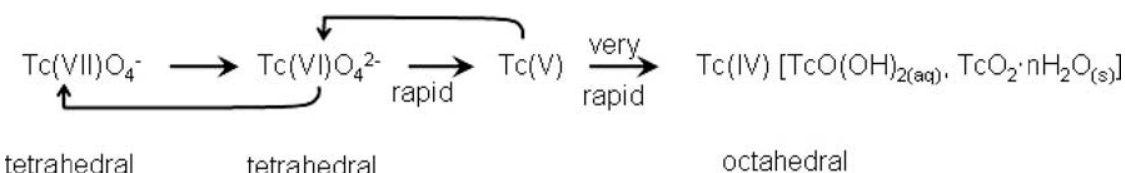

Fig. 11. General reaction mechanism and intermediate states for the 3-electron redox transformation of $\mathrm{Tc}(\mathrm{VII})$ to $\mathrm{Te}(\mathrm{IV})$ involving disproportionation as described by Cui and Eriksen (1996a) and Rard et al. (1999). 
surements indicate that the oxidized Fe(II) at the interface adopts magnetic ordering and hence, structural configuration comparable to the bulk Fe(III) oxide (Williams and Scherer, 2004, 2005). Silvester et al. (2005) hypothesized that the initial adsorption and subsequent redox reaction of sorbed Fe(II) occurs on crystal growth sites. Molecular calculations imply the plausibility of such redox reaction, suggesting that it is driven by the greater thermodynamic stability of $\mathrm{Fe}$ (III) as compared to $\mathrm{Fe}(\mathrm{II})$ surface species. The phenomena results in delocalization of negative charge density (from sorbed $\mathrm{Fe}(\mathrm{II})$ ) to the bulk solid several atomic layers from the interface (Kerisit and Rosso, 2006).

Our RT and $77 \mathrm{~K}$ Mössbauer measurements of ${ }^{57} \mathrm{Fe}(\mathrm{II})$ on ${ }^{56} \mathrm{Fe}$-goethite both before and after reaction with $\mathrm{Tc}$ (VII) (Fig. 3) were similar to ${ }^{57} \mathrm{Fe}$ (II) on ${ }^{56} \mathrm{Fe}$-goethite/ natural goethite reported by Silvester et al. (2005), Williams and Scherer (2004), implying oxidation of surface ${ }^{57} \mathrm{Fe}(\mathrm{II})$ by electron transfer to the bulk oxide, and its conversion to a goethite-like layer. Broadening of our Mössbauer spectra implied the possible presence of multiple Fe(III) environments with slightly different Mössbauer parameters, that were empirically fit with three sites (A, B, and C). While these findings were expected for the unreacted, $\mathrm{Fe}(\mathrm{II})$-sorbed goethite; they were not expected for the $\mathrm{Tc}(\mathrm{VII})$-reacted goethite that had experienced heterogeneous surface $\mathrm{Tc}(\mathrm{IV})$ precipitation, heterogeneous $\mathrm{Fe}(\mathrm{II})$ oxidation (at the interface or in bulk), and a second, coincident phase of $\mathrm{Fe}(\mathrm{II})$ sorption that renewed the initial $\mathrm{Fe}(\mathrm{II})$ sorption density (e.g., Figs. 1 and 2). Additional ${ }^{57} \mathrm{Fe}-\mathrm{Mössbauer}$ measurements are needed on the products of this heterogeneous reaction with both hematite and goethite to clearly identify the structural state of Fe(III) associated with Tc(IV). Technetium(IV) EXAFS appears to be relatively insensitive to the nature of the heterogeneous $\mathrm{Fe}(\mathrm{III})$ product, and may be an inadequate structural probe for co-associated $\mathrm{Fe}(\mathrm{III})$. Moreover, the Tc(IV)-goethite and -hematite EXAFS standards may have been compromised by the acid synthesis procedure. An alternative synthesis procedure for the reference phases is needed that does not subject the $\mathrm{Fe}(\mathrm{III})$ oxide sorbents to extremes in $\mathrm{pH}$.

Uncertainty exists on whether dissolved $\mathrm{Fe}(\mathrm{II})$ is an essential partner in heterogeneous redox reactions of the type studied here as suggested by Williams and Scherer (2004), Park and Dempsey (2005), and others. Williams and Scherer (2004) found that the sorbed Fe(II) on goethite (that displayed a Mössbauer spectra like that in Fig. 3a) was unreactive to nitroaromatic compounds (NAC) in the absence of $\mathrm{Fe}^{2+}{ }_{(\mathrm{aq})}$. Park and Dempsey (2005) proposed an anode/cathode model for the heterogeneous oxidation of sorbed $\mathrm{Fe}(\mathrm{II})$ on goethite where the reduction of dissolved oxygen at electron-rich, interfacial regions of sorbed $\mathrm{Fe}(\mathrm{II})$ is coupled to the oxidation of aqueous $\mathrm{Fe}(\mathrm{II})$ at electron poor regions with consequent structural incorporation of product $\mathrm{Fe}(\mathrm{III})$. Implicit in this conceptual model is (i) the presence of multiple sites or faces that may exhibit different adsorption affinities for $\mathrm{Fe}^{2+}{ }_{(\mathrm{aq})}$ and different intrinsic crystal growth rates as has been measured experimentally (Weidler et al., 1998; Chun et al., 2006), and (ii) the plausibility of significant bulk electron diffusion in both goethite and hematite as suggested by molecular modeling (Kerisit and Rosso, 2006). Our results (Figs. 1 and 2) showed clearly that $\mathrm{Tc}(\mathrm{VII})$ reduction was coincident with a stoichiometric event of $\mathrm{Fe}^{2+}{ }_{(\mathrm{aq})}$ adsorption at all $\mathrm{pH}$ values studied, consistent with the model of Park and Dempsey (2005).

\subsubsection{Phyllosilicates}

The heterogeneous reduction behavior of $\mathrm{Tc}(\mathrm{VII})$ in FRC-phyllosilicate mixture was similar to recent observations of the reactivity of NAC with DCB-reduced, Fe-containing phyllosilicates. Hofstetter et al. (2003, 2006) found that ion-exchangeable $\mathrm{Fe}(\mathrm{II})$ on reduced phyllosilicates was not reactive toward NAC. Moreover, NAC reduction showed little $\mathrm{pH}$ dependence, as did $\mathrm{Tc}(\mathrm{VII})$ reduction with the FRC-dcb, leading to the conclusion (Hofstetter et al., 2006) that edge-complexed $\mathrm{Fe}(\mathrm{II})$ made minor contribution to the heterogeneous reduction reaction, as the reactivity of $\mathrm{Fe}(\mathrm{II})$ edge complexes typically show strong $\mathrm{pH}$ dependency through hydrolysis (Klausen et al., 1995). Hofstetter et al. $(2003,2006)$ concluded that electron transfer occurred primarily from structural $\mathrm{Fe}(\mathrm{II})$ in the octahedral layer and that the Fe content, distribution and arrangement of $\mathrm{Fe}(\mathrm{II})$ and $\mathrm{Fe}(\mathrm{III})$ in the octahedral layer controlled heterogeneous redox reactivity for NAC. Structural Fe(II) in the octahedral layer of the fine-grained phyllosilicates was probably the primary $\mathrm{Fe}(\mathrm{II})$ species responsible for $\mathrm{Tc}(\mathrm{VII})$ reduction given our preparation procedure $\left(\mathrm{CaCl}_{2} / \mathrm{PIPES}\right.$ washing).

As compared to Tc(IV) associated with hematite and goethite, the redox product on the FRC-dcb showed more Tc-Tc bonding (Fig. 9), and less Fe(III) in the second coordination shell. The presence of a large amount of Tc-Tc bonding could be explained in two ways: (1) the coexistence of $\mathrm{TcO}_{2} \cdot n \mathrm{H}_{2} \mathrm{O}$ and $\mathrm{Tc}(\mathrm{IV})-\mathrm{Fe}(\mathrm{III})$ complexes similar to those observed on goethite and hematite, and (2) short (several octahedral units) lengths of $\mathrm{TcO}_{2}$ chains bound to $\mathrm{Fe}(\mathrm{III})$ associated with the phyllosilicate substrate. The presence of identifiable Fe scatterers in the Tc(IV) precipitate, may support our posit of electron transfer from submicron sized-phyllosilicates where a significant fraction of reaction sites exist along crystallite edges where structural, octahedral $\mathrm{Fe}$ is exposed. Alternatively, it may indicate that a portion of the heterogeneous reaction centers were edgecomplexed $\mathrm{Fe}(\mathrm{II})$ (e.g., to aluminol sites) where the reaction product was free to coprecipitate with Tc after electron transfer and disproportionation. Whether the greater amount of Tc-Tc bonding in the Tc(IV) precipitate in the FRC-dcb as compared to the Fe(III) oxide sorbents was a result of $\mathrm{Fe}(\mathrm{II})$ location, or kinetic factors such as a slower reduction rate was not ascertained.

\subsection{Comparisons of reduction/precipitation mechanisms with NAC}

Analogies have been drawn herein between the behavior of $\mathrm{Tc}(\mathrm{VII})$ and NAC because of similarities in certain experimental results. NACs are highly suited as redox probe compounds because they exhibit a range in reactivities and redox potentials (Rugge et al., 1998; Hofstetter 
et al., 2003, 2006; Elsner et al., 2004; Williams and Scherer, 2004). The reduced product is generally weakly adsorbed by the mineral substrate, allowing for study of how electron transfer influences the morphology and growth of the heterogeneous substrate in the absence of potentially inhibitory, strongly sorbing redox products (e.g., Chun et al., 2006).

A critical difference between NAC and Tc, however is that the reduced $\mathrm{Tc}(\mathrm{IV})$ product is quite insoluble $\left(<10^{-8} \mathrm{~mol} \mathrm{~L}^{-1}\right.$ depending on its molecular speciation), strongly associates with the solid surface as a surface precipitate or complex, and likely displays limited diffusional mobility after reaching the Tc(IV) state and hydrolyzing. Consequently, $\mathrm{Tc}(\mathrm{IV})$, which has a similar ionic radii $(0.645 \AA)$ to $\mathrm{Fe}(\mathrm{III})(0.640 \AA)$, is available at the interface to complex with or cover crystal nucleation sites; inhibit redox-initiated, face-specific growth (Chun et al., 2006); and/ or coprecipitate within new Fe(III) oxide phases formed by heterogeneous $\mathrm{Fe}(\mathrm{II})$ oxidation as limited by structural and charge balance constraints. These reactions influence the speciation of the $\mathrm{Tc}(\mathrm{IV}) / \mathrm{Fe}(\mathrm{III})$ redox product investigated herein, and distinguish Tc behavior and the resulting $\mathrm{Fe}(\mathrm{III})$ redox products from those generated by reaction with NAC.

\subsection{Geochemical implications}

New results presented herein demonstrate that mineral associated $\mathrm{Fe}(\mathrm{II})$ can be an effective heterogeneous reductant of Tc(VII) under anoxic conditions, yielding insoluble Tc(IV) precipitates, coprecipitates, and/or surface complexes that may significantly retard Tc migration. The heterogeneous process is orders of magnitude more rapid than the homogeneous reduction of $\mathrm{Tc}(\mathrm{VII})$ by $\mathrm{Fe}^{2+}(\mathrm{aq})$. Sorbed $\mathrm{Fe}(\mathrm{II})$ on $\mathrm{Fe}$ (III) oxides is a more rapid heterogeneous reductant of $\mathrm{Tc}(\mathrm{VII})$ than is structural/edge-complexed $\mathrm{Fe}(\mathrm{II})$ within or on layer silicates. The more rapid reduction rate promoted by the $\mathrm{Fe}(\mathrm{III})$ oxide system is attributed to more favorable thermodynamics of sorbed Fe(II) resulting from its hydroxylation, and the unique, but still poorly understood redox chemistry of $\mathrm{Fe}(\mathrm{II})$ at and within the near surface region of crystalline $\mathrm{Fe}(\mathrm{III})$ oxides. The large noted difference in heterogeneous reduction rates for the $\mathrm{Fe}(\mathrm{III})$ oxide versus phyllosilicate systems, were equivalent to differences noted in whole sediment dominated by these phases where $\mathrm{Fe}(\mathrm{II})$ was of biotic origin (Fredrickson et al., 2004). Vandergraaf et al. (1984) noted that Tc accumulated along grain boundaries of $\mathrm{Fe}$ (III) oxides in anoxic granitic and gabbro rock thin sections and not on mineral surfaces containing significant structural Fe(II) (such as biotite, pyroxene, or hornblende), an observation consistent with the importance the heterogeneous reaction on $\mathrm{Fe}(\mathrm{III})$ oxide surfaces. Ferrous iron associated with ferric oxides was also the dominant reductant for NAC in anaerobic aquifer sediments (Rugge et al., 1998).

Given that ${ }^{99} \mathrm{Tc}$ concentrations as an environmental contaminant are generally low (e.g., $<10^{-5} \mathrm{~mol} \mathrm{~L}^{-1}$ ), our results suggest that heterogeneous $\mathrm{Tc}(\mathrm{VII})$ reduction should occur rapidly in anoxic subsurface sediments at $\mathrm{pH}>6$ that contain even small amounts of goethite or hematite, and $\mathrm{Fe}_{(\mathrm{aq})}^{2+}$ of either abiotic or biotic origin.
The slower, but still significant heterogeneous reduction rates of $\mathrm{Tc}(\mathrm{VII})$ on reduced phyllosilicates of "average" total $\mathrm{Fe}(\mathrm{II})$ content as studied here, suggest that this process should also be important in subsurface sediments where layer silicates are typically ubiquitous, and often reduced. Moreover, ferrous containing phyllosilicates may contain effectively large structural repositories of electron equivalents (Amonette, 2002) allowing their function as long-term, flux-capturing reductive sinks of ${ }^{99} \mathrm{Tc}$ (e.g., Istok et al., 2004). The different molecular speciation of heterogeneous reduction products on $\mathrm{Fe}$ (III) oxides and layer silicates is expected to strongly influence their oxidation rates (e.g., Zachara et al., 2007) if and when molecular oxygen concentrations increase in bathing subsurface or sediment pore waters.

\section{ACKNOWLEDGMENTS}

We would like to thank Paul Gassman for ${ }^{56} \mathrm{Fe}$-goethite synthesis; Steven Smith and Andrew Plymale for preparation and characterization of FRC-dcb sediments and for performing preliminary $\mathrm{Tc}(\mathrm{VII})$ reduction experiments by $\mathrm{Fe}(\mathrm{II})$ adsorbed on $\mathrm{Fe}(\mathrm{III})$ oxides. The research was supported by the Environmental Remediation Sciences Program (ERSP), Office of Biological and Environmental Research (OBER), Environmental Remediation Sciences Division (ERSD), U.S. Department of Energy (DOE). Mössbauer spectroscopy measurements were performed in the Environmental Molecular Sciences Laboratory (EMSL) that is managed and supported by OBER-ERSD. PNNL is operated for the DOE by Battelle. PNC/XOR facilities at the Advanced Photon Source, and research at these facilities, are supported by the U.S. Department of Energy Basic Energy Sciences, a major facilities access grant from NSERC, the University of Washington, Simon Fraser University, the Pacific Northwest National Laboratory and the Advanced Photon Source. Use of the Advanced Photon Source is also supported by the U.S. Department of Energy, Office of Science, Office of Basic Energy Sciences, under Contract DEAC02-06CH11357.

\section{REFERENCES}

Amonette J. E. (2002) Iron redox chemistry of clays and oxides: environmental applications. In: Electrochemical Properties of Clays, CMS Workshop Lectures (ed. A. Fitch). The Clay Mineral Society, Aurora, CO.

Amonette J. E., Workman D. J., Kennedy D. W., Fruchter J. S. and Gorby Y. A. (2000) Dechlorination of carbon tetrachloride by $\mathrm{Fe}(\mathrm{II})$ associated with goethite. Environ. Sci. Technol. 34, 4606-4613.

Anschutz A. J. and Penn R. L. (2005) Reduction of crystalline iron(III) oxyhydroxides using hydroquinone: influence of phase and particle size. Geochem. Trans. 6, 60-66.

Bain D. C. and Smith B. F. (1994) Spectroscopic and chemical determinative methods. In Clay Mineralogy (ed. M. J. Wilson). Chapman and Hall, London.

Behrends T. and Van Cappellen P. (2005) Competition between enzymatic and abiotic reduction of uranium(VI) under iron reducing conditions. Chem. Geol. 220, 315-327.

Bennett R. and Willey N. (2003) Soil availability, plant uptake and soil to plant transfer of Tc-99-a review. J. Environ. Radiol. 65, 215-231.

Bondietti E. A. and Francis C. W. (1979) Geologic migration potentials of Tc-99 and Np-237. Science 203, 1337-1340. 
Buerge I. J. and Hug S. J. (1999) Influence of mineral surfaces on chromium(VI) reduction by iron(II). Environ. Sci. Technol. 33, 4285-4291.

Burke I. T., Boothman C., Lloyd J. R., Mortimer R. J. G., Livens F. R. and Morris K. (2005) Effects of progressive anoxia on the solubility of technetium in sediments. Environ. Sci. Technol. 39, 4109-4116.

Charlet L. and Tournassat C. (2005) $\mathrm{Fe}(\mathrm{II})-\mathrm{Na}(\mathrm{I})-\mathrm{Ca}(\mathrm{II})$ cation exchange on montmorillonite in chloride medium: evidence for preferential clay adsorption of chloride - metal ion pairs in seawater. Aquat. Geochem. 11, 115-137.

Charlet L., Silvester E. and Liger E. (1998) N-compound reduction and actinide immobilization in surficial fluids by $\mathrm{Fe}(\mathrm{II})$ : the surface $\mathrm{Fe}(\mathrm{III}) \mathrm{OFe}(\mathrm{II}) \mathrm{OH}$ degrees species, as major reductant. Chem. Geol. 151, 85-93.

Chun C. L., Penn R. L. and Arnold W. A. (2006) Kinetic and microscopic studies of reductive transformations of organic contaminants on goethite. Environ. Sci. Technol. 40, 3299-3304.

Coby A. J. and Picardal F. W. (2005) Inhibition of $\mathrm{NO}_{3}{ }^{-}$and $\mathrm{NO}_{2}{ }^{-}$reduction by microbial $\mathrm{Fe}(\mathrm{III})$ reduction: Evidence of a reaction between $\mathrm{NO}_{2}{ }^{-}$and cell surface-bound $\mathrm{Fe}^{2+}$. Appl. Environ. Microbiol. 71, 5267-5274.

Colon D., Weber E. J. and Anderson J. L. (2006) QSAR study of the reduction of nitroaromatics by $\mathrm{Fe}(\mathrm{II})$ species. Environ. Sci. Technol. 40, 4976-4982.

Cornell R. M. and Schwertmann U. (2000) The Iron Oxides: Structure, Properties, Reactions, Occurrences, and Uses. Wiley$\mathrm{VCH}$, New York.

Cui D. Q. and Eriksen T. E. (1996a) Reduction of pertechnetate by ferrous iron in solution: influence of sorbed and precipitated Fe(II). Environ. Sci. Technol. 30, 2259-2262.

Cui D. Q. and Eriksen T. E. (1996b) Reduction of pertechnetate in solution by heterogeneous electron transfer from $\mathrm{Fe}(\mathrm{II})$-containing geological material. Environ. Sci. Technol. 30, 22632269.

Elsner M., Schwarzenbach R. P. and Haderlein S. B. (2004) Reactivity of $\mathrm{Fe}(\mathrm{II})$-bearing minerals toward reductive transformation of organic contaminants. Environ. Sci. Technol. 38, 799-807.

Fredrickson J. K., Zachara J. M., Kennedy D. W., Dong H. L., Onstott T. C., Hinman N. W. and Li S. M. (1998) Biogenic iron mineralization accompanying the dissimilatory reduction of hydrous ferric oxide by a groundwater bacterium. Geochim. Cosmochim. Acta 62, 3239-3257.

Fredrickson J. K., Zachara J. M., Kennedy D. W., Kukkadapu R. K., McKinley J. P., Heald S. M., Liu C. X. and Plymale A. E. (2004) Reduction of $\mathrm{TcO}_{4}{ }^{-}$by sediment-associated biogenic $\mathrm{Fe}(\mathrm{II})$. Geochim. Cosmochim. Acta 68, 3171-3187.

Gregory K. B., Larese-Casanova P., Parkin G. F. and Scherer M. M. (2004) Abiotic transformation of hexahydro-1,3,5-trinitro1,3,5-triazine by $\mathrm{Fe}(\mathrm{II})$ bound to magnetite. Environ. Sci. Technol. 38, 1408-1414.

Haderlein S. B. and Pecher K. (1999) Pollutant reduction in heterogeneous $\mathrm{Fe}(\mathrm{II}) / \mathrm{Fe}(\mathrm{III})$-systems. In Kinetics and Mechanisms of Reactions at the Mineral/Water Interface (eds. D. L. Sparks and T. J. Grundl). American Chemical Society.

Hansen H. C. B., Koch C. B., Nancke-Krogh H., Borggaard O. K. and Sorensen J. (1996) Abiotic nitrate reduction to ammonium: key role of green rust. Environ. Sci. Technol. 30, 2053-2056.

Hess N. J., Yuanxian X., Rai D. and Conradson S. D. (2004) Thermodynamic model for the solubility of $\mathrm{TcO}_{2} \cdot x \mathrm{H}_{2} \mathrm{O}(\mathrm{am})$ in the aqueous $\mathrm{Tc}(\mathrm{IV})-\mathrm{Na}^{+}-\mathrm{Cl}^{-}-\mathrm{H}^{+}-\mathrm{OH}^{-}-\mathrm{H}_{2} \mathrm{O}$ system. J. Solution Chem. 33, 199-226.

Hofstetter T. B., Schwarzenbach R. P. and Haderlein S. B. (2003) Reactivity of $\mathrm{Fe}(\mathrm{II})$ species associated with clay minerals. Environ. Sci. Technol. 37, 519-528.
Hofstetter T. B., Neumann A. and Schwarzenbach R. P. (2006) Reduction of nitroaromatic compounds by $\mathrm{Fe}(\mathrm{II})$ species associated with iron-rich smectites. Environ. Sci. Technol. 40, 235-242.

Holta P., Hautojarvi A. and Hakanen M. (1992) Transport and retardation of non-sorbing radionuclides in crystalline rock fractures. Radiochim. Acta 58/59, 285-290.

Hyacinthe C., Bonneville S. and Van Cappellen P. (2006) Reactive iron(III) in sediments: chemical versus microbial extractions. Geochim. Cosmochim. Acta 70, 4166-4180.

Istok J. D., Senko J. M., Krumholz L. R., Watson D., Bogle M. A., Peacock A., Chang J.-Y. and White D. C. (2004) In situ bioreduction of technetium and uranium in a nitrite-contaminated aquifer. Environ. Sci. Technol. 38, 468-475.

Jang J. H., Dempsey B. A. and Burgos W. D. (2007) Solubility of hematite revisited: effects of hydration. Environ. Sci. Technol. 41, 7303-7308.

Jeon B. H., Dempsey B. A., Burgos W. D. and Royer R. A. (2001) Reactions of ferrous iron with hematite. Colloids Surf. A: Physicochem. Eng. Aspects 191, 41-55.

Jeon B. H., Dempsey B. A. and Burgos W. D. (2003) Kinetics and mechanisms for reactions of $\mathrm{Fe}(\mathrm{II})$ with iron(III) oxides. Environ. Sci. Technol. 37, 3309-3315.

Jeon B. H., Dempsey B. A., Royer R. A. and Burgos W. D. (2004) Low-temperature oxygen trap for maintaining strict anoxic conditions. J. Environ. Eng. ASCE 130, 1407-1410.

Jeon B. H., Dempsey B. A., Burgos W. D., Barnett M. O. and Roden E. E. (2005) Chemical reduction of U(VI) by Fe(II) at the solid-water interface using natural and synthetic Fe(III) oxides. Environ. Sci. Technol. 39, 5642-5649.

Jolivet J. P., Tronc E., Barbe C. and Livage J. (1990) Interfacial electron-transfer in colloidal spinel iron-oxide silver ion reduction in aqueous-medium. J. Colloid Interf. Sci. 138, 465-472.

Kerisit S. and Rosso K. (2006) Computer simulation of electron transfer at hematite surfaces. Geochim. Cosmochim. Acta 70, 1888-1903.

Kim S. and Picardal F. W. (1999) Enhanced anaerobic biotransformation of carbon tetrachloride in the presence of reduced iron oxides. Environ. Toxicol. Chem. 18, 2142-2150.

Klausen J., Trober S. P., Haderlein S. B. and Schwarzenbach R. P. (1995) Reduction of substituted nitrobenzenes by $\mathrm{Fe}(\mathrm{II})$ in aqueous mineral suspensions. Environ. Sci. Technol. 29, 23962404.

Komadel P., Lear P. R. and Stucki J. W. (1990) Reduction and reoxidation of nontronite: extent of reduction and reaction rates. Clays Clay Miner. 38, 203-208.

Komlos J., Kukkadapu R. K., Zachara J. M. and Jaffe P. R. (2007) Biostimulation of iron reduction and subsequent oxidation of sediment containing Fe-silicates and Fe-oxides: effect of redox cycling on Fe(III) bioreduction. Water Res. 41(13), 2996-3007.

Kukkadapu R. K., Zachara J. M., Smith S. C., Fredrickson J. K. and Liu C. X. (2001) Dissimilatory bacterial reduction of Alsubstituted goethite in subsurface sediments. Geochim. Cosmochim. Acta 65, 2913-2924.

Kukkadapu R. K., Zachara J. M., Fredrickson J. K., McKinley J. P., Kennedy D. W., Smith S. C. and Dong H. L. (2006) Reductive biotransformation of Fe in shale-limestone saprolite containing $\mathrm{Fe}(\mathrm{III})$ oxides and $\mathrm{Fe}(\mathrm{II}) / \mathrm{Fe}(\mathrm{III})$ phyllosilicates. Geochim. Cosmochim. Acta 70, 3662-3676.

Larsen O., Postma D. and Jakobsen R. (2006) The reactivity of iron oxides towards reductive dissolution with ascorbic acid in a shallow sandy aquifer (Romo, Denmark). Geochim. Cosmochim. Acta 70, 4827-4835.

Lear P. R. and Stucki J. W. (1987) Intervalence electron transfer and magnetic exchange in reduced nontronite. Clays Clay Miner. 35, 373-378. 
Lieser K. H. and Bauscher C. (1987) Technetium in the hydrosphere and in the geosphere. 1. Chemistry of technetium and iron in natural-waters and influence of the redox potential on the sorption of technetium. Radiochim. Acta 42, 205-213.

Liger E., Charlet L. and Van Cappellen P. (1999) Surface catalysis of uranium(VI) reduction by iron(II). Geochim. Cosmochim. Acta 63, 2939-2955.

Liu C., Zachara J. M., Foster-Mills N. S. and Strickland J. (2007) Kinetics of reductive dissolution of hematite by bioreduced anthraquinone-2,6-disulfonate. Environ. Sci. Technol. 41, 77307735.

Lloyd J. R., Sole V. A., Van Praagh C. V. G. and Lovley D. R. (2000) Direct and Fe(II)-mediated reduction of technetium by Fe(III)-reducing bacteria. Appl. Environ. Microbiol. 66, 37433749.

Lukens, Jr., W. W., Bucher J. J., Edelstein N. M. and Shuh D. K. (2002) Products of pertechnetate radiolysis in highly alkaline solution: Structure of $\mathrm{TcO}_{2} \cdot x \mathrm{H}_{2} \mathrm{O}$. Environ. Sci. Technol. 36, 1124-1129.

Murad E. and Cashion J. (2004) Mössbauer Spectroscopy of Environmental Materials and their Industrial Utilization. Kluwer Academic Publishers, Dordrecht.

Park B. and Dempsey B. A. (2005) Heterogeneous oxidation of $\mathrm{Fe}(\mathrm{II})$ on ferric oxide at neutral $\mathrm{pH}$ and a low partial pressure of $\mathrm{O}_{2}$. Environ. Sci. Technol. 39, 5000-6494.

Pecher K., Haderlein S. B. and Schwarzenbach R. P. (2002) Reduction of polyhalogenated methanes by surface-bound $\mathrm{Fe}(\mathrm{II})$ in aqueous suspensions of iron oxides. Environ. Sci. Technol. 36, 1734-1741.

Pepper S. E., Bunker D. J., Bryan N. D., Livens F. R., Charnock J. M., Pattrick R. A. D. and Collison D. (2003) Treatment of radioactive wastes: an X-ray absorption spectroscopy study of the reaction of technetium with green rust. J. Colloids Interf. Sci. 268, 408-412.

Rancourt d. G. and Ping J. Y. (1991) Voigt-based methods for arbitrary-shape static hyperfine parameter distributions in Mossbauer spectroscopy. Nucl. Instrum. Methods Phys. Rev. B58, 85-87.

Rard J. A., Rand M. H., Anderegg G. and Wanner H. (1999) Chemical Thermodynamics of Technetium. Elsevier, Amsterdam, The Netherlands.

Ravel B. and Newville M. (2005) ATHENA, ARTEMIS, HEPHAESTUS; data analysis for X-ray absorption spectroscopy using IFEFFIT. J. Synchrotron Radiat. 12, 537-541.

Rehr J. J. and Albers R. C. (2000) Theoretical approaches to X-ray absorption fine structure. Rev. Mod. Phys. 72, 621-654.

Roden E. E. (2004) Analysis of long-term bacterial vs. chemical $\mathrm{Fe}(\mathrm{III})$ oxide reduction kinetics. Geochim. Cosmochim. Acta $\mathbf{6 8}$, 3205-3216.

Rugge K., Hofstetter T. B., Haderlein S. B., Bjerg P. L., Knudsen S., Zraunig C., Mosbaek H. and Christensen T. H. (1998) Characterization of predominant reductants in an anaerobic leachate-contaminated aquifer by nitroaromatic probe compounds. Environ. Sci. Technol. 32, 23-31.

Schroeder N. C., Morgan D., Rokop D. J. and Fabryka-Martin J. (1993) Migration of technetium-99 in the alluvial aquifer at the Nevada test site, Nevada. Radiochim. Acta 60, 203-209.

Schwertmann U. and Cornell R. M. (2000) Iron Oxides in the Laboratory. Wiley-VCH, Weiheim, Germany.

Serne R. J. and Mann F. M. (2004) Preliminary Data from 216-B26 Borehole in BC Cribs Area. RPP-20303, Rev. 0, CH2M Hill Hanford Group, Inc., Richland, WA.

Silvester E., Charlet L., Tournassat C., Gehin A., Greneche J. M. and Liger E. (2005) Redox potential measurements and Mossbauer spectrometry of $\mathrm{Fe}(\mathrm{II})$ adsorbed onto $\mathrm{Fe}(\mathrm{III})$ (oxyhydr)oxides. Geochim. Cosmochim. Acta 69, 4801-4815.
Sorensen J. and Thorling L. (1991) Stimulation by lepidocrocite ( $\gamma$ $\mathrm{FeOOH})$ of $\mathrm{Fe}(\mathrm{II})$-dependent nitrite reduction. Geochim. Cosmochim. Acta 55, 1289-1294.

Strathmann T. J. and Stone A. T. (2003) Mineral surface catalysis of reactions between $\mathrm{Fe}(\mathrm{II})$ and oxime carbamate pesticides. Geochim. Cosmochim. Acta 67, 2775-2791.

Stucki J. W., Golden D. C. and Roth C. B. (1984) Effects of reduction and reoxidation of structural iron on the surface charge and dissolution of dioctahedral smectites. Clays Clay Miner. 32, 350-356.

Stucki J. W., Lee K., Goodman B. A. and Kostka J. C. (2007) Effects of in-situ biostimulation on iron mineral speciation in a subsurface soil. Geochim. Cosmochim. Acta. 72(4), 834-843.

Stumm W. and Sulzberger B. (1992) The cycling of iron in natural environments - considerations based on laboratory studies of heterogeneous redox processes. Geochim. Cosmochim. Acta 56, 3233-3257.

Szecsody J. E., Fruchter J. S., Williams M. D., Vermeul V. R. and Sklarew D. (2004) In situ chemical reduction of aquifer sediments: enhancement of reactive iron phases and TCE dechlorination. Environ. Sci. Technol. 38, 4656-4663.

Vandergraaf T. T., Ticknor K. V. and George I. M. (1984) Reactions between technetium in solution and iron-containing minerals under oxic and anoxic conditions. In Geochemical Behavior of Disposed Radioactive Waste (eds. G. S. Barney, J. D. Navratil and W. W. Schulz). American Chemical Society, Washington, DC.

Ward A. L., Gee G. W., Zhang Z. F. and Keller J. M. (2004) Vadose Zone Contaminant Fate and Transport Analysis for the 216-B-26 Trench. PNNL-14907, Pacific Northwest National Laboratory, Richland, WA.

Weidler P. G., Hug S. J., Wetche T. P. and Hiemstra T. (1998) Determination of growth rates of (100) and (110) faces of synthetic goethite by scanning force microscopy. Geochim. Cosmochim. Acta 62, 3407-3412.

Wharton M. J., Atkins B., Charnok J. M., Livens F. R., Pattrick R. A. D. and Collison D. (2000) An X-ray adsorption spectroscopy study of the coprecipitation of Tc and Re with macinawite (FeS). Appl. Geochem. 15, 347-354.

Wildung R. E., Mcfadden K. M. and Garland T. R. (1979) Technetium sources and behavior in the environment. $J$. Environ. Qual. 8, 156-161.

Wildung R. E., Gorby Y. A., Krupka K. M., Hess N. J., Li S. W., Plymale A. E., McKinley J. P. and Fredrickson J. K. (2000) Effect of electron donor and solution chemistry on products of dissimilatory reduction of technetium by Shewanella putrefaciens. Appl. Environ. Microbiol. 66, 2451-2460.

Wildung R. E., Li S. W., Murray C. J., Krupka K. M., Xie Y., Hess N. J. and Roden E. E. (2004) Technetium reduction in sediments of a shallow aquifer exhibiting dissimilatory iron reduction potential. FEMS Microbiol. Ecol. 49, 151-162.

Williams A. G. B. and Scherer M. M. (2004) Spectroscopic evidence for $\mathrm{Fe}(\mathrm{II})-\mathrm{Fe}(\mathrm{III})$ electron transfer at the iron oxidewater interface. Environ. Sci. Technol. 38, 4782-4790.

Zachara J. M., Fredrickson J. K., Li S. M., Kennedy D. W., Smith S. C. and Gassman P. L. (1998) Bacterial reduction of crystalline $\mathrm{Fe}^{3+}$ oxides in single phase suspensions and subsurface materials. Am. Mineral. 83, 1426-1443.

Zachara J. M., Heald S. M., Jeon B. H., Kukkadapu R. K., Liu C., McKinley J. P., Dohnalkova A. C. and Moore D. A. (2007) Reduction of pertechnetate $[\mathrm{Tc}(\mathrm{VII})]$ by aqueous $\mathrm{Fe}(\mathrm{II})$ and the nature of solid phase redox products. Geochim. Cosmochim. Acta. 71, 2137-2157.

Associate editor: Donald L. Sparks 